This is the author-accepted manuscript for the article: Agliardi, E., Agliardi, R., Pinar, M., Stengos, T. and Topaloglou, N. (2012) A new country risk index for emerging markets: A stochastic dominance approach. Journal of Empirical Finance, 19 (5). pp. 741-761. ISSN 0927-5398 doi:10.1016/j.jempfin.2012.08.003

(C) 2016. This manuscript version is made available under the CC-BY-NC-ND 4.0 license http://creativecommons.org/licenses/by-nc-nd/4.0 


\title{
A new country risk index for emerging markets: a stochastic dominance approach
}

\author{
March 19, 2012
}

\begin{abstract}
An optimal weighting scheme is proposed to construct economic, political and financial risk indices in emerging markets using an approach that relies on consistent tests for stochastic dominance efficiency. These tests are considered for a given risk index with respect to all possible indices constructed from a set of individual risk factors. The test statistics and the estimators are computed using mixed integer programming methods. We derive an economic, political and financial risk ranking of emerging countries. Finally, an overall risk index is constructed. One main result is that the financial risk is the leading contributor to sovereign risk in emerging markets followed by the economic and political risk.
\end{abstract}

JEL Classifications: C12; C13; C14; C15; G01

Key Words: Nonparametric Stochastic Dominance,

Mixed Integer Programming; Sovereign Risk; Emerging economies. 


\section{Introduction}

There is a growing awareness that sovereign debt crises can quickly mushroom - as events in a number of emerging countries in the late 1990s have shown (Sturzenegger and Zettelmeyer (2006)) and, more recently, as a consequence of the global economic and financial crisis, that affected public debt and sovereign risk, hitting developed and emerging countries with varying intensity and persistence.

It is also a common understanding that emerging economies are prone to financial crises and some of the major financial crises affecting emerging markets in recent years have been linked to risky external and domestic debt composition, rollover risks, contingent interest payments and the poor credibility of monetary and fiscal policies (see Eichengreen and Hausmann (2005); Hausmann and Panizza (2003); Jeanne (2003); Zettelmeyer and Jeanne (2002)). Rating downgrades were relatively rare until the 1990s, and when they occurred, were of modest size and manageable. Nowadays, the credit quality of the sovereign sector is by far more heterogeneous and unstable ${ }^{1}$. Also in view of the globalized dimension of economic and financial markets, country risk assessment has become a more urgent matter now than ever.

And yet, there is no good understanding of the sources of vulnerability and of the determinants of country risk. Whether the problem is a weak banking sector, an excessive public or private sector external burden, some structural impediment to growth, lack of transparency of a country's political institutions - just to mention a few of the determinants considered by most providers of risk ratings - a satisfactory comprehensive measure of country risk is still to be found. A good index of country risk is also crucial for strengthening the policy response towards economic improvement and sovereign creditworthiness. The objective of our paper is to derive a new country risk index for emerging markets that outperforms the most common existing sovereign risk indicators and, at the same time, allows us to disentangle the contributions of economic, political and financial risk factors.

There are many services measuring country risk. Among the foremost providers of risk ratings, there are: the International Country Risk Guide (ICRG); the Institutional Investors (II); the Business Environment Risk Intelligence (BERI); the Economist Intelligence Unit (EIU); Euromoney; and services of the major rating agencies, that is, Standard \& Poor's; Moody's and Fitch. The synopsis in Figure 1 compares these indices.

All the above-mentioned indices are based on arbitrary weighting of the relevant variables and most of them share the conventional wisdom that political risk is the key determinant.

Relatively little research has focused on the construction of a country risk

\footnotetext{
${ }^{1}$ The rising threat of instability from sovereign debt problems worsened conditions in the global financial system recently and is bound to derail the global recovery, according to the International Monetary Fund, Stability Report: "sovereign risks remain elevated as markets continue to focus on high public debt burdens, unfavourable growth dynamics, increased rollover risks, and linkages to the banking system" (5 Oct 2010).
} 
index. Erb et al. (1999) explained this lack of academic work, especially for emerging markets, because of the short time series that exist, making it very difficult to produce an accurate evaluation of the characteristics of the market. To the best of our knowledge, the only work analyzing some measures of country risk is Erb et al. (1996). They explore the political, economic, financial and composite risk index from ICRG and the II country credit ratings and provide a comparison of S\&P's and Moody's ratings. They find out that rank order correlation is higher between S\&P's or Moody's rating and the ICRG financial risk index. Moreover, through the construction of a portfolio of countries that experienced a decrease in risk rating and a portfolio of countries that experienced an increase in risk rating, they investigate whether the risk indices contain information about future expected returns. They find that the financial risk index contains the most information about future expected returns and the political risk contains the least.

A broad literature has studied which factors determine or affect a country's "ability" and "willingness to pay". A first group of contributions investigates the determinants of sovereign credit ratings. In their seminal paper, Cantor and Packer (1996a) use regression analysis to measure the relative significance of eight variables that are listed in Moody's and Standard and Poor's reports and show that GDP growth, per capita income, external debt, inflation and indicator variables for economic development and default history are the main determinants of the ratings issued by S\&P and Moody's. Afonso (2003) updates Cantor and Packer (1996a) and finds analogous outcomes. A further updating is in Afonso, Gomes and Rother (2011), where a distinction between shortand long-run determinants of sovereign ratings is introduced. They show that the level of GDP per capita, real GDP growth, public debt level and the government balance sheet have a consistent short-run impact, while the level of external debt and external reserves together with government effectiveness are important long-run determinants. Another set of works examine the relationship between spreads and sovereign ratings. Cantor and Packer (1996b) find that agency disagreements over sovereign ratings are quite common and that the rank orderings of sovereign risks implied by market yields frequently differs from the ratings assigned by the agencies. In particular, financial markets seem to be more pessimistic about sovereign credit risk than are the rating agencies, meaning that rating agencies undervalue the perception of financial risk. Such differences of opinion appear to be most extreme for below investment-grade countries. An updated comparison of sovereign ratings is in Flandreau et al. (2009) and in Afonso, Furceri and Gomes (2011), where possible spillover effects from lower rated countries to higher rated countries are also considered. A recent work, assessing the effect of sovereign credit rating announcements on sovereign CDS spreads for emerging markets, is Ismalescu and Kazemi (2010).

There is a large empirical literature based on regression analyses that treat a debt crisis as the dependent variable and a number of economic, political and institutional variables as independent variables. The latter typically include solvency indicators such as the ratio of debt to GDP, GDP growth, the real exchange rate, liquidity indicators and the level of international reserves. Several 
recent papers, such as Reinhart (2002), Catao and Sutton (2002), Reinhart et al. (2003), Van Rijckeghem and Weder (2004), Kruger and Messmacher (2004), Catao and Kapur (2004), have included other institutional and political variables, debt history, financing needs indicators and macroeconomic volatility. Some studies investigate the effects of macroeconomic fundamentals on sovereign credit spreads, under the view that a higher yield spread reflects higher risk. Hilscher and Nosbuch (2010) focus on terms of trade for emerging markets and examine the relative importance of country-specific and global factors. Hui and Lo (2002) develop a model to value defaultable bonds and focus on foreign exchange rates as the main variable to track the credit spreads in some emerging markets. Eichengreen and Mody (1998) conclude that changes in market sentiment, not obviously related to fundamentals, have moved the markets by large amounts.

The results from these studies are in keeping with most theories about "the ability to pay" and the "willingness to pay", and stress that sovereign debt risk crises tend to occur more often the higher the debt to GDP ratio, the lower growth, the lower reserves, the higher the financing needs and the worse the quality of the institutions.

A serious shortcoming is that the construction of the above country risk measures, as in the case of the separate analysis of single attributes, ignores the association among the various risk factors. In this paper we will follow an approach for the construction of aggregate indices for economic, political and financial risk in emerging countries based on stochastic dominance (SD hereafter) analysis. Constructing an optimal country risk index based on SD analysis has advantages since it provides an efficient index resulting from the least variable combination of risk factors that offers the maximum level of risk environment over time for each country or group of countries. Moreover, relatively large data sets are available, so that nonparametric analysis can let the data "speak for themselves". The optimality of the index refers to the fact that it gives the greatest value of risk environment for economic, political and financial sectors in emerging countries. In other words, we will construct an index with those weights given to each risk factor in each sub-index that will make it stochastically dominate all other competitor indices.

Mostly, stochastic dominance comparisons are made pair wise in the literature. Barrett and Donald (2003) developed pair wise stochastic dominance comparisons that relied on Kolmogorov-Smirnov type tests developed within a consistent testing environment. This offers a generalization to Anderson (1996), Beach and Davidson (1983), Davidson and Duclos (2000) who have looked at second order stochastic dominance using tests that rely on pairwise comparisons made at a fixed number of arbitrarily chosen points. This is not a desirable feature since it introduces the possibility of a test inconsistency. Linton et al. (2005) propose a subsampling method which can deal with both dependent samples and dependent observations within samples. This is appropriate for conducting SD analysis with country panel data. In this context, comparisons were available for pairs where one can compare risk levels in one year relative to previous years and conclude whether there is a higher presence of risk or 
not. Gonzalo and Olmo (2010) introduce nonparametric consistent tests of conditional stochastic dominance of arbitrary order in a dynamic setting. Both Linton et al. (2005) and Gonzalo and Olmo (2010) propose consistent SD tests, which could be applied also to sovereign risk analysis; however, although both tests allow for comparison over time and among different risk factors, they are restricted to pairwise comparisons only. Lately, multi-variate (multidimensional) comparisons have become more popular. In an application to optimal portfolio construction in finance, Scaillet and Topaloglou (2010), hereafter ST, use SD efficiency tests that can compare a given portfolio with an optimal diversified portfolio constructed from a set of assets. In a related paper, Pinar et al. (2012) use a similar approach to construct an optimal Human Development Index. In this paper we follow the same methodology, using the set of risk variables (in our case economic, political, and financial risk factors for each respective index) to construct the optimal economic, political, and financial risk indices that do not rely on arbitrary weights as rating institutions do.

An arbitrary weight to each risk factor would assign a predetermined or "perceived" importance of it. It is possible that the importance of some risk factors may change over time and may be different for different groups of countries. Some risk factors which are included in the overall risk index may become obsolete and some other risk factors which are excluded from the analysis may gain importance over time. In other words, as time passes, the evolution of risk factors for different groups of countries can vary over time (e.g., a new set of country coverage may add new characteristics of risk to the existing ones, and/or risk factors for any given cross section of countries may change over time). Therefore, weights assigned to each risk factor may have to be re-estimated over time ${ }^{2}$. The main contribution of this paper is to derive an optimal country risk index based on SD efficiency analysis. We use consistent SD efficiency analysis to determine the optimal weights assessing the relative importance of the risk factors for emerging market economies. By using SD efficiency analysis, we test the optimality of the equally-weighted risk index with respect to all possible weighting combinations of risk factors and obtain the optimal risk index by maximizing the cumulative risk difference between a given index (i.e. equally-weighted risk index) and the alternative one. Therefore, the optimal risk index offers the riskiest factors that are persistently high for emerging market economies rather than predetermined arbitrary weights, which are commonly used by rating institutions.

The index we obtain will offer the maximum level of risk environment in emerging markets for a given probability level and also be the least volatile over time among its set of competitors. By weighting each risk factor differently, we find the riskiest economic, political and financial environment for a larger number of countries over time than under the arbitrary weighted risk measures

\footnotetext{
${ }^{2}$ In a related SD application, Pinar et al. (2012) carries out Monte Carlo simulations allowing new observations with heterogeneous characteristics to enter the existing data set. They found that the entrance of new observations with different statistical characteristics will result in a $2 \%$ to $3 \%$ change in the relative weights attached to the individual components (see Pinar et al. 2012, Section 5.1).
} 
offered by rating institutions. We also find the weighting scheme of each subindex (i.e. economic, political and financial risk) which offers the overall riskiest environment for the emerging economies.

Our findings have relevant policy implications too. The optimal economic, political, financial and overall risk indices highlight the riskiest factors which are persistently high for the majority of the emerging countries over time. This implies that an emerging country should adjust its agenda consequently in order to keep sovereign risk under control. We also find that the financial risk index is the main contributor to overall risk for emerging markets. Thus, our analysis is able to capture the growing expansion of the financial sector in emerging countries and the leading role of monetary and financial institutions. Finally, our paper contributes to the current debate on the reliability of the rating assignment by $\mathrm{S} \& \mathrm{P}$ and its sister rating agencies. We show that our index is not affected by their documented reluctancy to change the rating class and asymmetry between the upgrading and downgrading moves.

The remainder of the paper is as follows. In section 2 we examine the main framework of analysis, define the notions of stochastic dominance and discuss the general hypothesis for stochastic dominance of any order. In section 3 the mathematical formulation of the tests is presented. Section 4 develops the empirical analysis. We first look at the data used for economic, political and financial indices and offer descriptive statistics and use the ST methodology to find the optimal index for economic, political, financial and overall risk environment for emerging markets. Then we rank the countries for each sub-index and the overall risk environment. A comparative analysis with the rankings of the main rating agencies is offered too. Finally, section 5 concludes. In the appendix we describe practical ways to compute p-values for testing stochastic dominance efficiency at any order by looking at block bootstrap methods and discuss the theoretical justification for these methods.

\section{Hypothesis, Test Statistics and Asymptotic Properties}

We consider a strictly stationary process $\left\{\boldsymbol{Y}_{t} ; t \in \mathbb{Z}\right\}$ taking values in $\mathbb{R}^{n}$. The observations consist in a realization of $\left\{\boldsymbol{Y}_{t} ; t=1, \ldots, T\right\}$. These data correspond to observed values of the $n$ different constituent components of the given equally weighted risk index $(\boldsymbol{\tau})$. We denote by $F(\boldsymbol{y})$, the continuous cdf of $\boldsymbol{Y}=\left(Y_{1}, \ldots, Y_{n}\right)^{\prime}$ at point $\boldsymbol{y}=\left(y_{1}, \ldots, y_{n}\right)^{\prime}$.

Let us consider a composite risk index $\boldsymbol{\lambda} \in \mathbb{L}$ where $\mathbb{L}:=\left\{\boldsymbol{\lambda} \in \mathbb{R}_{+}^{n}: \boldsymbol{e}^{\prime} \boldsymbol{\lambda}=1\right\}$ and $\boldsymbol{e}$ is a vector made of ones. This means that all the different components have positive weight and that the composite index weights sum to one. Let us denote by $G(z, \boldsymbol{\lambda} ; F)$ the cdf of the composite index value $\boldsymbol{\lambda}^{\prime} \boldsymbol{Y}$ at point $z$ given by $G(z, \boldsymbol{\lambda} ; F):=\int_{\mathbb{R}^{n}} \mathbb{I}\left\{\boldsymbol{\lambda}^{\prime} \boldsymbol{u} \leq z\right\} d F(\boldsymbol{u})$. 
Further define for $z \in \mathbb{R}$ :

$$
\begin{aligned}
& \mathcal{J}_{1}(z, \boldsymbol{\lambda} ; F):=G(z, \boldsymbol{\lambda} ; F), \\
& \mathcal{J}_{2}(z, \boldsymbol{\lambda} ; F):=\int_{-\infty}^{z} G(u, \boldsymbol{\lambda} ; F) d u=\int_{-\infty}^{z} \mathcal{J}_{1}(u, \boldsymbol{\lambda} ; F) d u, \\
& \mathcal{J}_{3}(z, \boldsymbol{\lambda} ; F):=\int_{-\infty}^{z} \int_{-\infty}^{u} G(v, \boldsymbol{\lambda} ; F) d v d u=\int_{-\infty}^{z} \mathcal{J}_{2}(u, \boldsymbol{\lambda} ; F) d u,
\end{aligned}
$$

and so on.

From Davidson and Duclos (2000) Equation (2), we know that

$$
\mathcal{J}_{j}(z, \boldsymbol{\lambda} ; F)=\int_{-\infty}^{z} \frac{1}{(j-1) !}(z-u)^{j-1} d G(u, \boldsymbol{\lambda}, F),
$$

which can be rewritten as

$$
\mathcal{J}_{j}(z, \boldsymbol{\lambda} ; F)=\int_{\mathbb{R}^{n}} \frac{1}{(j-1) !}\left(z-\boldsymbol{\lambda}^{\prime} \boldsymbol{u}\right)^{j-1} \mathbb{I}\left\{\boldsymbol{\lambda}^{\prime} \boldsymbol{u} \leq z\right\} d F(\boldsymbol{u}) .
$$

The general hypotheses for testing the stochastic dominance efficiency of order $j$ of $\boldsymbol{\tau}$, hereafter $S D E_{j}$, can be written compactly as:

$$
\begin{array}{ll}
H_{0}^{j}: \mathcal{J}_{j}(z, \boldsymbol{\tau} ; F) \leq \mathcal{J}_{j}(z, \boldsymbol{\lambda} ; F) & \text { for all } z \in \mathbb{R} \text { and for all } \boldsymbol{\lambda} \in \mathbb{L}, \\
H_{1}^{j}: \mathcal{J}_{j}(z, \boldsymbol{\tau} ; F)>\mathcal{J}_{j}(z, \boldsymbol{\lambda} ; F) & \text { for some } z \in \mathbb{R} \text { or for some } \boldsymbol{\lambda} \in \mathbb{L} .
\end{array}
$$

Under the null Hypothesis $H_{0}^{j}$ there is no hybrid index $\lambda$ constructed from the set of risk factors that dominates the index $\tau$ at order $j$. In this case, the function $\mathcal{J}_{j}(z, \tau ; F)$ is always lower than the function $\mathcal{J}_{j}(z, \lambda ; F)$ for all possible hybrid indices $\lambda$ for any risk level $z$. Under the alternative hypothesis $H_{1}^{j}$, we can construct a hybrid index $\lambda$ that for some risk level $z$, the function $\mathcal{J}_{j}(z, \tau ; F)$ is greater than the function $\mathcal{J}_{j}(z, \lambda ; F)$. Thus, when $j=1$, the index $\tau$ is stochastically inefficient at first order if and only if some other hybrid index $\lambda$ dominates it at some risk level $z$. Alternatively, the index $\tau$ is stochastically efficient at first order if and only if there is no hybrid index $\lambda$ that dominates it at all risk levels.

In particular we obtain SD at first and second order when $j=1$ and $j=2$, respectively. The hypothesis for testing SD of order $j$ of the distribution of index $\tau$ over the distribution of index $\lambda$ takes analogous forms, but for a given $\lambda$ instead of several of them.

\subsection{Tests of the optimality of an index}

Following ST and Pinar et al. (2012), the distribution of the hybrid index $\lambda$ dominates the distribution of the fixed weight risk index $\tau$ stochastically at first order (SD1) if, for any risk level $z, G(z, \tau ; F) \geq G(z, \lambda ; F)$. If $z$ denotes a risk level, then the inequality in the definition means that the proportion of countries 
in distribution $\lambda$ with value of risk outcome smaller than $z$ is not larger than the proportion of such countries in $\tau$. In other words, there is at least as high a proportion of risk level in $\lambda$ as in $\tau$. If the composite index $\lambda$ dominates the index $\tau$ at first order, then there is always lower risk in $\tau$ than in $\lambda$, so that $\lambda$ suggests a riskier environment. We test whether the composite economic, political and financial risk index is optimally constructed using arbitrary weights (i.e. equal weights to each risk factor in respective index), or whether we can obtain an alternative composite index with optimal weights for the different constituent risk components of the composite index which implies a riskier environment. Thus, we test whether the equally weighted risk index is optimal, or whether we can construct a composite index $\boldsymbol{\lambda}$ from the set of the risk components in the respective index that dominates the index.

The general hypotheses for testing the optimality of an equally-weighted risk index $\tau$, can be written compactly as:

$$
\begin{array}{ll}
H_{0}: G(z, \boldsymbol{\tau} ; F) \leq G(z, \boldsymbol{\lambda} ; F) & \text { for all } z \in \mathbb{R} \text { and for all } \boldsymbol{\lambda} \in \mathbb{L}, \\
H_{1}: G(z, \boldsymbol{\tau} ; F)>G(z, \boldsymbol{\lambda} ; F) & \text { for some } z \in \mathbb{R} \text { or for some } \boldsymbol{\lambda} \in \mathbb{L} .
\end{array}
$$

The empirical counterpart is simply obtained by integrating with respect to the empirical distribution $\hat{F}$ of $F$, which yields:

$$
\mathcal{J}_{j}(z, \boldsymbol{\lambda} ; \hat{F})=\frac{1}{T} \sum_{t=1}^{T} \frac{1}{(j-1) !}\left(z-\boldsymbol{\lambda}^{\prime} \boldsymbol{Y}_{t}\right)^{j-1} \mathbb{I}\left\{\boldsymbol{\lambda}^{\prime} \boldsymbol{Y}_{t} \leq z\right\}
$$

and can be rewritten more compactly for $j \geq 2$ as:

$$
\mathcal{J}_{j}(z, \boldsymbol{\lambda} ; \hat{F})=\frac{1}{T} \sum_{t=1}^{T} \frac{1}{(j-1) !}\left(z-\boldsymbol{\lambda}^{\prime} \boldsymbol{Y}_{t}\right)_{+}^{j-1}
$$

\subsection{Test Statistics and Asymptotic Distributions}

The asymptotic distribution of $\hat{F}$ is given by $\sqrt{T}(\hat{F}-F)$ which tends weakly to a mean zero Gaussian process $\mathcal{B} \circ F$ in the space of continuous functions on $\mathbb{R}^{n}$ (see e.g. the multivariate functional central limit theorem for stationary strongly mixing sequences stated in Rio (2000)). ST (2010) derive the limiting behavior by using the Continuous Mapping Theorem (as in Lemma 1 of Barrett and Donald (2003)), see ST (2010) Lemma 2.1.

We consider the weighted Kolmogorov-Smirnov type test statistic

$$
\hat{S}_{j}:=\sqrt{T} \frac{1}{T} \sup _{z, \boldsymbol{\lambda}}\left[\mathcal{J}_{j}(z, \boldsymbol{\tau} ; \hat{F})-\mathcal{J}_{j}(z, \boldsymbol{\lambda} ; \hat{F})\right],
$$

and a test based on the decision rule:

$$
\text { " reject } H_{0}^{j} \text { if } \hat{S}_{j}>c_{j} "
$$

where $c_{j}$ is some critical value. (The derivation of the test is given by ST (2010)). 
In order to make the result operational, we need to find an appropriate critical value $c_{j}$. Since the distribution of the test statistic depends on the underlying distribution, this is not an easy task, and we decide hereafter to rely on a block bootstrap method to simulate $p$-values. The block bootstrap method works well with a limited number of time dependent data (i.e., 200 to 450 observations in our empirical application) and also uses full sample information ${ }^{3}$.

\section{Mathematical formulation of the test statis- tics}

The test statistic $\hat{S}_{1}$ for first order stochastic dominance efficiency is derived using mixed integer programming formulations. The following is the full formulation of the model:

$$
\begin{array}{ll}
\max _{\mathbf{z}, \boldsymbol{\lambda}} \hat{S}_{1}=\sqrt{T} \frac{1}{T} \sum_{t=1}^{T}\left(L_{t}-W_{t}\right) & \\
\text { s.t. } & M\left(L_{t}-1\right) \leq z-\boldsymbol{\tau}^{\prime} \mathbf{Y}_{t} \leq M L_{t}, \quad \forall t \\
& M\left(W_{t}-1\right) \leq z-\boldsymbol{\lambda}^{\prime} \mathbf{Y}_{t} \leq M W_{t}, \quad \forall t \\
& \boldsymbol{e}^{\prime} \boldsymbol{\lambda}=1, \\
& \boldsymbol{\lambda} \geq 0, \\
& W_{t} \in\{0,1\}, L_{t} \in\{0,1\}, \quad \forall t
\end{array}
$$

with $M$ being a large constant.

The model is a mixed integer program maximizing the distance between the sum over all scenarios of two binary variables, $\frac{1}{T} \sum_{t=1}^{T} L_{t}$ and $\frac{1}{T} \sum_{t=1}^{T} W_{t}$ which represent $G(z, \boldsymbol{\tau} ; \hat{F})$ and $G(z, \boldsymbol{\lambda} ; \hat{F})$, respectively (the empirical cdf of $\boldsymbol{\tau}$ and $\boldsymbol{\lambda}$ at risk level $z$ ). According to inequalities (2b), $L_{t}$ equals 1 for each scenario $t \in T$ for which $z \geq \boldsymbol{\tau}^{\prime} \boldsymbol{Y}_{t}$, and 0 otherwise. Analogously, inequalities (2c) ensure that $W_{t}$ equals 1 for each scenario for which $z \geq \boldsymbol{\lambda}^{\prime} \boldsymbol{Y}_{t}$. Equation (2d) defines the sum of all portfolio weights to be unity, while inequality (2e) disallows negative weights.

This formulation allows us to test the dominance of the equally weighted risk index $(\boldsymbol{\tau})$ over any potential linear combination $\boldsymbol{\lambda}$ of the risk factors that are in the respective index.

When some of the variables are binary, corresponding to mixed integer programming, the problem becomes NP-complete (non-polynomial, i.e., formally intractable). The problem can be reformulated in order to reduce the solving

\footnotetext{
${ }^{3}$ The block size is set to $l=10$. ST (2010) test for their block sizes ranging from $l=4$ to $l=16$ by step of 4 and find that the choice of block size does not change the performance of their methodology. Similarly, different block sizes are allowed here and the results do not change significantly.
} 
time and to obtain a tractable formulation (see ST (2010), section 4.1 and the appendix for the derivation of this formulation and details on practical implementation).

\section{Empirical Analysis}

\subsection{Data and Descriptive Statistics}

We use 34 variables in total to capture the risk outcomes in the economic, political and financial environments for emerging countries. The choice of these variables is based on earlier studies aiming at identifying the potential determinants of sovereign defaults and on the existing services measuring country risk. The data set used in the analysis consists of annual data for several emerging countries. The main sources are the International Financial Statistics (IFS) from the International Monetary Fund, the Economist Intelligence Unit (EIU) and national sources. Some data begin in 1980, but not all countries have data going back that far. A detailed description of variables and sources is included in Table $1^{4}$.

Not only are economic and financial risk variables measured on different scales, but also a higher value in any of these variables may indicate a riskier or a less risky environment for a country and as such these variables may not be strictly comparable. As a result, we need to resort to normalization by scaling each variable to unit range as: $x_{i j t}=\frac{X_{i j t}-\min X_{j}}{\max X_{j}-\min X_{j}}$, where $X_{i j t}$ represents an outcome of variable $j$ for country $i$ at time $t$ and $x_{i j t}$ is the normalized outcome of the variable in the range between 0 and 1 .

Similarly, we normalize the political risk variables, so that each variable lies in the 0 - 1 range. After normalization, we convert the values taken by each variable so that higher values correspond to more risk. If a variable affects a country's sovereign risk positively, then we normalize the variable to be $x_{i j t}$, however if a variable affects a country's sovereign risk negatively, then we convert the normalized outcome to be $1-x_{i j t}$.

We use economic performance data consisting of nine macroeconomic variables that affect a sovereign's ability to service its debt. Variables that are used to calculate the economic risk are: budget balance/GDP, current account/GDP, total external debt/GDP, public debt/GDP, terms of trade, percentage change of GDP, inflation, total debt per capita and effective maturity. The economic performance data form an unbalanced panel of 24 emerging countries over the time period 1980 to 2010. The first panel of Table $2 \mathrm{~A}$ presents the summary statistics of each variable after linear scaling to unit range.

The political risk data consist of 16 rating variables, four of which scale up to 10 and the remaining twelve scale up to 5 . The group of the first four consists of the variables: EIU political environment rating (PERT hereafter), EIU policy environment for foreign investment rating (FIRT hereafter), EIU political

\footnotetext{
${ }^{4}$ The authors are indebted to ABI Country Risk Forum staff members for their invaluable help in providing most data.
} 
stability rating (PSER hereafter) and institutional effectiveness rating (IEER hereafter). They are all scaled between 1 and 10, with 1 denoting the worst and 10 the best policy environment. The four rating variables that are scaled to 10 form a balanced data set of 32 emerging market countries for the period 19952010 (the only exception is Azerbaijan for the period 1998-2010). The twelve rating variables that are scaled to 5 are: risk of armed conflict (ACER hereafter), risk of social unrest (SUER hereafter), terrorism threat (TRER hereafter), international disputes and tensions (IDER hereafter), government stance towards business (GBER hereafter), effectiveness of system in policy implementation (PIER hereafter), quality of bureaucracy (QBER hereafter), transparency and fairness of legal system (ROFL hereafter), level of corruption (CRER hereafter), impact of crime (ICER hereafter), degree of property rights protection (PRRT hereafter), and fairness of tax system (TSER hereafter) with 1 denoting the worst and 5 the best political environment for all of these. The group of rating variables that are scaled to 5 forms a balanced data of 32 countries for the period 1994-2010 (with the exception of Azerbaijan for the period for 1998-2010 and the Kazakhstan and Ukraine ratings for period 1995-2010). The second panel of Table $2 \mathrm{~A}$ presents the summary statistics of the rating variables that are scaled to unit range.

The financial and banking sector data set consists of nine variables: 1) banking sector risk is scaled between 0 to 100 , with 100 being the highest banking sector risk; 2) composite stock market index in local currency ${ }^{5}$; 3) lending interest rate, commercial banks average lending rate to non-financial enterprises; 4) money market interest rate, weighted average yield on 13 week Treasury bills; 5) loans/assets, a liquidity ratio that indicates what percentage of the assets of the bank are tied up in loans where the higher this ratio the less liquid the banking system will be; 6 ) increase in interest arrears, i.e. change in cumulative stock of unpaid interest charges due on long-term external debt at end-period; 7) increase in principal arrears, i.e. change in cumulative stock of overdue principal repayments on long-term external debt at end-period; 8) percentage change in M1, total supply of notes and coins plus demand deposits at end-period, over the previous year; and 9) percentage change in M2 plus quasi-money at end-period, over the previous year. The third panel of Table $2 \mathrm{~A}$ presents the summary statistics of financial and banking sector variables after linear scaling to unit range.

The three panels of Table 2B represent the summary statistics of economic, political and financial risk factors respectively before the linear scaling to unit range.

\footnotetext{
${ }^{5}$ The composite stock market index is in local currency, therefore, this variable is normalized within the country. The highest and lowest stock market values experienced by a country over time are used for normalization. Therefore, normalized values are obtained separately for each country.
} 


\subsection{Stationarity of the risk indices}

In the previous section, we converted economic, political, financial and banking sector variables into risk indices where higher index values represent a higher risk environment. SD efficiency analysis requires the use of stationary data and, as such, we would need to examine the properties of the risk factors in each sub-index before applying SD efficiency tests. In this section, we test whether the risk factor indices constructed from the actual variables are following a stationarity process by using standard Augmented Dickey-Fuller (ADF) unit root tests. We use three different ADF lag length decision criteria, Schwartz information criterion (SBIC), Akaike's information criterion (AIC), and the Hannan and Quinn information criterion (HQIC) and report all the test statistics for each risk index in Table 3. Overall, all risk indices follow a stationary process and as such we can proceed to apply the ST (2010) methodology to test for the equally-weighted sub-indices (economic, political, financial and banking sector risk environment) for the whole emerging markets group ${ }^{6}$.

We should note that even though the risk factor indices follow a stationary process, some of the variables for some countries follow a unit root process. In the case of non-stationarity, rather than using the ST (2010) approach, one can use the Linton et al. (2005) consistent tests of stochastic dominance under general sampling schemes which allow for serial and mutual dependence between random variables. Linton et al. (2005) use the subsampling method to approximate the asymptotic null distributions of their test statistics which works well in "many cases where the standard bootstrap fails: in heavy tailed distributions, in unit root cases, in cases where the parameter is on the boundary of its space, etc". Moreover, Gonzalo and Olmo (2010) improve on Linton et al. (2005) method with nonparametric application which avoids parametric specification of the data generating process and allows for general forms of serial and mutual dependence between stationary processes. Hence, both Linton et al. (2005) and Gonzalo and Olmo (2010) consistent tests can be applied for the sovereign risk analysis at a country level (i.e., whether one risk factor at a given country is riskier when compared with another country). However, our analysis is to examine the overall risk in emerging markets at a given time horizon rather than consider a pairwise country specific risk analysis. Since each risk factor index follows a stationary process in economic, political and financial and banking sector categories, in the next section, we employ the ST (2010) stochastic dominance efficiency analysis to test whether a use of equally-weighted risk in each sub-category is efficient or any alternative weighting can assign a higher risk environment for emerging markets.

\footnotetext{
${ }^{6}$ Even though some variables for some countries are nonstationary when these variables are put into an index and are cointegrated, then their linear combination, the index, is stationary. In the current application, we use the indices for all emerging markets to measure the overall risk for all the countries under consideration rather than individual variables or variables for given countries alone. Therefore, for the purpose of the present application, we test for stationarity of the overall risk factor indices in each category.
} 


\subsection{Results for the efficiency of sovereign risk indices}

This section presents our findings of the test for SD1 efficiency of each sub-index (i.e. economic, political, and financial and banking sector). We find that the arbitrarily weighted risk ratings are not optimal. We compute the weighting scheme of each respective factor in each sub-index, which offers the riskiest environment for emerging economies.

We proceed to construct many other hybrid composites $\lambda$ consisting of the nine components of economic performance (i.e. budget balance/GDP, current account/GDP, total external debt/GDP, public debt/GDP, terms of trade, \% in change of GDP, inflation, total debt per capita and effective maturity) that stochastically dominate the equally weighted risk environment $\tau$, in the first order sense (e.g. for which $G(z, \tau ; F)>G(z, \lambda ; F)$ ). There are 450 different such composite $\lambda$ 's. The first panel in Table 4 summarizes the results. This table presents the average weights of the 450 hybrid composites that dominate the equally weighted risk outcomes. It is clear that GDP growth has the greatest impact with a $52.1 \%$ weight. On the other hand, terms of trade and budget balance/GDP take weights of $31.5 \%$ and $15.7 \%$ respectively. Total debt per head and current account balance/GDP have the least impact on economic risk with weights of $0.5 \%$ and $0.2 \%$ respectively. The inefficiency of the equally-weighted economic risk index indicates that it is suboptimal. One can see that there are three major factors that affect the economic risk of emerging market countries. If a country is experiencing slow or negative growth, a negative budget balance and/or adverse terms of trade, then a sovereign debt crisis might be triggered. Real GDP growth and the government budget balance to GDP ratio are traditional solvency variables which are most commonly used both in the literature and in the country risk measures assigned by rating services. The important contribution of terms of trade and its changes in affecting a country's ability to generate dollar revenue from exports - and thus to service external dollar denominated debt - has been extensively recognized in the literature (Bulow and Rogoff (1989), Mendoza (1995), Chen and Rogoff (2003), Hilscher and Nosbusch (2010)). Our analysis attaches an insignificant role to current account balance to GDP ratio, which is often employed as a solvency variable. However, this economic variable turns out to be of less significance also in some other studies (see Baek et al. (2005), for example). Finally, debt-to-GDP ratio is a widely used indicator of a country's solvency and the probability of default, which makes our result counter-intuitive. However, the debt level does not shed much light on the debt service burden if it is not accompanied by data on its composition, yield and maturity structure. More importantly, debt ratios "may not be very good measures of even the concept that they are supposed to proxy, namely, a country's ability to pay, or solvency" (Sturzenegger and Zettelmeyer (2006)). Solvency is intrinsically an intertemporal concept and analyses primarily focusing on the debt-to-GDP ratio fail to capture the complexity of credit events and the uncertainty in forecasting whether public debt remains on a sustainable path. On one hand, a dynamic measure of sustainable debt should also take into account the growth rate of GDP, primary surpluses and interest rates 
(Abiad and Ostry (2005)). On the other hand, the contingent claim approach (see Gapen et al. (2005), Gray et al. (2006), Gray and Malone (2008)), while providing a new tool for debt sustainability analysis, has stressed the theoretical weakness and poor predictive power of an accounting ratio like debt-to-GDP, which is "a static backward-looking indicator" (Gapen et al. (2005)).

Using the same methodology, we construct many other hybrid composites $\lambda$ consisting of the 16 components of the political performance (i.e. PERT, FIRT, PSER, IEER, ACER, SUER, TRER, IDER, GBER, PIER, QBER, ROFL, CRER, ICER, PRRT, and TSER) that stochastically dominate the equally weighted risk index $\tau$, in the first order sense (e.g. for which $G(z, \tau ; F)>$ $G(z, \lambda ; F))$. There are 493 different such composite $\lambda$ 's. The second panel in Table 4 summarizes the results. This table presents the average weights of the 493 hybrid composites that dominate the equally weighted risk outcomes. The most significant political risk factors - in decreasing order - are the level of corruption, the lack of transparency and fairness of legal system, the institutional effectiveness, the impact of violent crime, the quality of bureaucracy and the degree of property rights protection, while external factors play an insignificant role.

We follow the same analysis for the financial/banking risk assessment. We can construct many other hybrid composites $\lambda$ consisting of the nine risk variables of the financial and banking sector (i.e. banking sector risk, stock market index, lending interest rate, money market interest rate, loans/assets, increase in interest and principal arrears, percentage change in M1 and M2) that stochastically dominate the equal weight risk environment $\tau$, in the first order sense. At every risk level, $z$, there is always a $\lambda$ that dominates the equally weighted risk index $\tau$. The third panel in Table 4 presents the average weights of the $232 \mathrm{hy}-$ brid composites that dominate the equally weighted financial risk outcomes. We find that the percentage change in M1 contributes the most for financial risk with $41.5 \%$ followed by banking sector risk, stock market index, loan/assets, and the percentage change in M2 with average weights of $34.4 \%, 16 \%, 4.6 \%$ and $3.5 \%$ respectively. As for the financial index, our outcome is that the driving factor is the percentage change in M1, which is the classical measure of liquidity of a country. Indeed, a country might be capable of repaying its long term debt, but might not have the cash to make a payment: in the absence of intervention by the official institutions or in the impossibility of rolling over existing debt, lack of liquidity will trigger default.

Finally, we find the weighting scheme of each risk factor for the economic, political and financial environment which offers the riskiest environment for each respective index. At this point, we follow a similar approach as in each subindex (i.e. economic, political and financial risk) to obtain the overall riskiest environment for emerging economies. To do so, we first obtain the economic, political and financial risk outcomes for each emerging country over time by using the weighting schemes proposed in Table 4 for each respective index. There are 19 countries that have overlapping risk outcomes for each sub-index with a total of 214 observations for the years between 1997 to 2008. We obtain the equally-weighted risk outcome for each country by averaging risk levels in 
economic, political and financial indices and test whether the equally-weighted overall risk index, $\tau$, is efficient or not. We find that we can construct many other hybrid composite risk indices $\lambda$ consisting of the 3 sub-index risk outcomes (i.e. economic, political and financial risk outcomes) that stochastically dominate the equally-weighted risk index, $\tau$, in the first order sense. Table 5 presents the average weights of the 190 hybrid composites that dominate the equallyweighted overall risk index. The results show that financial risk is the main contributor to sovereign risk in emerging markets with a $77.4 \%$ weight, followed by economic and political risk with a $14.8 \%$ and $7.8 \%$ weight, respectively. A spreadsheet to compute the sovereign risk indices for each country is available at: http://www.unibo.it/docenti/elettra.agliardi/countryrisk.

Our findings on the prevailing role of financial over economic and political indicators in assessing country risk is in line with the literature showing that the country risk premium in emerging markets is left unexplained if only changes in economic fundamentals are considered (Eichengreen and Mody (1998)) and that market attitude toward risk has a large impact on emerging market bond spreads (Min (1998), Baek et al. (2005)). As Baek et al. (2005) emphasize "the divergence between traditional gauges of country risk that are primarily based on the economic fundamentals of a country and the market-assessed risk premium is perhaps a result of changes in the general market mood towards risk in emerging countries". Our analysis, which employs also very recent data, is able to capture the growing development of the financial sector in emerging countries and the primary role of monetary policy and of international monetary institutions as key determinants of sovereign risk.

In the next subsection, we will present some ranking analysis with our optimal risk outcomes for each sub-index and overall risk for emerging countries and compare our optimal indices' rankings with the rankings of the rating agencies.

\subsection{Analysis with optimal risk indices}

In this section we first construct the country rankings using the optimal economic and political risk index, from riskiest to the least risky country for 2008, 2009 and 2010. The financial and banking sector and overall country risk rankings are presented for 2008 alone, since some data on the financial sector after 2008 are lacking. Table 6 presents the country risk rankings for each respective risk index. In the first panel of Table 6 economic risk rankings are offered for the years 2008, 2009 and 2010. In 2008, the riskiest emerging country in economic terms is Pakistan, followed by Hungary, Turkey, Thailand and Mexico. In 2009, except for Pakistan which moved to a lower risk ranking, the countries that had the riskiest economic environment in 2008 remained the riskiest in economic terms. Pakistan experienced better growth and improved terms of trade and had less of a negative budget balance in 2009 than in 2008. Other emerging countries that have higher economic risk outcomes in 2009 than in 2008 experienced at least a deterioration either in their economic growth or terms of trade and/or have a worse budget balance/GDP. In 2010, Hungary, Turkey and Thailand continued to be in a higher economic risk category, while Pakistan 
returned back to a higher economic risk environment. Overall risk outcomes in 2010 declined with respect to 2009 with the exception of Pakistan. After the 1998 default episode Pakistan reached debt rescheduling on extremely favorable terms. The government pursued macroeconomic stabilization and IMF intervened with a Stand-by-Arrangement of 7.6 billion $\$$ in November 2008 and more recently. But on the political side, the internal situation remains critical and tense. As for the financial and banking sector, while Pakistan's banks are considered to be well-capitalized, on the other hand they are heavily exposed to the government sector, which makes them vulnerable to sovereign shocks, like a natural disaster. This was the case with the recent floods that put pressure on the country's bank system and posed significant risks to the financial sector.

Once the global economic and financial crises took place in late 2008, the majority of emerging countries experienced a downturn (recession) in their economic outcomes in 2009 and had higher risk outcomes in 2009. However, there was an improvement in 2010 and their economic risk levels declined, with the exception of Pakistan. When we consider the least risky emerging country, Nigeria was the country which ranked as the least risky emerging country in economic terms, followed by China and Chile.

In the second panel of Table 6, we present the political risk rankings for emerging economies in 2008, 2009 and 2010. Emerging countries which have the riskiest political environment remained more or less stable over time with Nigeria, Venezuela, Kazakhstan, Azerbaijan and Ecuador being the top five politically risky countries over time. Note that Nigeria was the least risky country in economic terms, yet the riskiest in political terms. On the other hand, Chile, Malaysia, Hungary, Poland and South Africa are the least risky countries over time. It is worth noting that Chile is not only among the least risky countries in political terms but also in economic terms. Chile has benefited from the recent liberalization policy and trade openness promoted by its government, registering an increase in exports and a rise in income levels and consumer demand.

In the third panel of Table 6, we present the financial risk rankings for emerging economies in 2008, with Hungary, China and Ukraine being the riskiest countries and Poland, Mexico and Chile being the least risky ones in financial and banking sector terms. At the end of 2008 Hungary was indeed perceived as a very risky country and was attributed a negative watch by the rating agencies. Also Ukraine's vulnerability exacerbated in 2008 and was reflected in the devaluation of the national currency (almost 60\% devaluation of Ukrainian hryvnya against US\$ in 4th quarter 2008) which was detrimental to retail lending and dramatically affected the country's bank sector. In 2008 Ukraine's current account deficit increased, the macroeconomic indicators deteriorated and credit default swaps traded above 1000 bps. At the beginning of 2010 total assets of Ukrainian banking systems contracted by $30 \%$ compared to the 2008 pre-crisis level. After the approval of the stand-by arrangement by IMF, giving Ukraine immediate access to $\$ 2$ billion of financing, a rating upgrade occurred in 2010 . The high value of the financial risk index for China is in contrast with the risk assessment of the big rating agencies and the prevailing common wisdom, but is 
in line with the data on the problems that are lurking on China's bank balance sheets - in particular, the losses that may be incurred from loans made to development entities ( LGFVs) that are sponsored and supposedly guaranteed by provincial and local governments. According to some analysts at Bank of America-Merrill Lynch $23 \%$ of these loans are categorized as "facing high credit risks" and they might cause some $30 \%$ cut to bank earnings. While these lending category alarmed the Chinese government, there are other categories - loans to property developers, to industries with significant overcapacity, to overextended home buyers, to businesses that diverted the funds to stock and real estate speculation - that may expose Chinese banks to significant losses.

Finally, the fourth panel of Table 6 presents the overall risk in emerging countries. This is highly correlated with financial risk outcomes, since the main contributor to sovereign risk is driven by the financial and banking sectors. For overall risk, Hungary is the riskiest country in 2008 since it is the riskiest country in financial terms and second riskiest country in economic terms. Even though politically Hungary ranks a lower position, financial and economic risk environments are the main contributors to overall risk. Pakistan moved to a higher ranking in the ladder, since not only it has a high financial risk environment but also a high risk environment in economic terms.

We further consider whether our optimal sovereign risk rankings are significantly correlated or not with the rating agencies' rankings. The first panel of Table 7 presents the country rating rankings of S\&P and Fitch from the riskiest to least risky outcome for 2008, while the second panel of Table 7 presents the country rating rankings of the $\mathrm{S} \& \mathrm{P}$ from the riskiest to the least risky outcome in 2009 and 2010. We analyze whether there is a significant Spearman rank correlation between the rating agencies' rankings and our optimal risk rankings in each sub-index and whether changes in the S\&P ratings over time are similar to the changes using the optimal risk sub-indices.

Firstly, we show that the rating institutions' rankings are highly correlated, since we find the Spearman correlation coefficient between the S\&P and Fitch rankings to be 0.99. Table 8 presents the Spearman rank correlation coefficients between the rating companies' rankings and our optimal sub-index rankings. In the first panel of Table 8, we report the Spearman correlation coefficient between the S\&P rankings and the optimal economic, political, financial and overall risk rankings. There are 19 countries which have overlapping data for all optimal indices among the 32 emerging countries. We find that only our political rankings are positively correlated with the S\&P rankings at the 5\% significance level. However, we find no significant correlation between the optimal economic, financial and overall risk rankings and the S\&P ratings. In the second panel of Table 8, we compute the Spearman coefficient between the S\&P rankings and each optimal risk index ranking separately in order to use more countries for the analysis. The results are similar to those of the correlation coefficients with the 19 common countries. In the third and fourth panels of Table 8 the same analysis is done for the Fitch rating rankings. We consider the 18 countries which have overlapping data for all optimal risk indices. The findings are slightly different from those of the $\mathrm{S} \& \mathrm{P}$ ratings. 
We also examine the changes in the risk environment for the period 2008 to 2010 that covers much of the current global economic and financial crisis. The first panel of Table 7 presents the emerging countries' risk ratings by the S\&P for 2008 and the second panel of Table 7 for 2009 and 2010. Rating agencies, such as S\&P, generally produce stable ratings even in the outbreak of a global economic and financial crisis. The overall stability of rating is striking: for 17 out of a total 30 emerging countries, S\&P gave the same ratings in 2008 and 2009, for 7 countries the ratings changed slightly and for only 6 countries were there significant changes in ratings in 2009 relative to $2008^{7}$. Furthermore, changes in the S\&P country ratings are more stable going from 2009 to 2010 than from 2008 to 2009 as for 25 of 30 emerging countries the ratings in 2010 remained the same as those of $2009^{8}$. The overall stability of ratings is confirmed by various works (Gaillard (2007), Sy (2001)) investigating the correlation between the agencies' ratings and their agreement/disagreements with the market's view. It is stressed that the ratings from S\&P, Fitch - and even more Moody's remain unchanged after excessively high or low spreads, in many cases, and the relationship between rating and market spreads is weaker in times of market turbulence (see Ferri et al. (1999), who showed that S\&P and Moody's failed to predict the Asian crisis and even exacerbated it because of their alleged procyclical ratings). Another feature of the agencies' sovereign ratings is that the few rating changes are usually asymmetric. The three main agencies are more reluctant to upgrade when spreads are excessively low than downgrade when spreads are excessively high, showing an asymmetric trend that is stronger for the Fitch and Moody's than for S\&P. Our indices are not affected by such biased behavior. As an illustration we compare the performance of our risk index with the S\&P and Fitch ratings in the case of Argentina's sovereign default (see Figure 2). The agencies' ratings are mapped to a 0-100 scale and all the risk values are considered at the beginning of each year to allow for a comparison. Argentina defaulted on Jan. 3, 2002 and the bank rush started at the end of 2001. Our index provides an earlier warning than S\&P and Fitch that rated BB- at the beginning of 2001. S\&P rated SD only on Nov. 6, 2001 and Fitch rated DDD only on Dec. 3, 2001, while our index started moving upwards in the years preceding the default episodes.

With our optimal indices, we find that the changes in economic risk for emerging countries were dramatically different than those of the S\&P ratings. Almost all emerging countries' economic condition deteriorated from 2009 with the exception of Pakistan. Only 5 emerging countries have similar changes in our optimal economic risk index with respect to the changes in the S\&P ratings from 2008 to 2009. Pakistan's risk rating improved from 2008 to 2009 and Hungary, Mexico, Nigeria, and Ukraine's economic conditions deteriorated. From 2009 to 2010, only 3 countries have significant improvement in the $\mathrm{S} \& \mathrm{P}$ ratings, whereas

\footnotetext{
${ }^{7}$ Ecuador and Pakistan have major improvements in their ratings, SD to CCC + and $\mathrm{CCC}+$ to B- respectively. Hungary, Mexico, Nigeria and Ukraine have major deterioration in their ratings ( $\mathrm{BBB}$ to $\mathrm{BBB}-, \mathrm{BBB}+$ to $\mathrm{BBB}, \mathrm{BB}-$ to $\mathrm{B}+$, and $\mathrm{B}$ to $\mathrm{CCC}+$ respectively).

${ }^{8}$ Indonesia, Turkey and Ukraine have major improvements in their ratings, BB- to BB, $\mathrm{BB}$ - to $\mathrm{BB}$, and $\mathrm{CCC}+$ to $\mathrm{B}$ - respectively.
} 
with the optimal economic risk index, all countries except Pakistan improved their conditions.

One reason why the rankings obtained with the optimal indices differ significantly from the rankings of the $\mathrm{S} \& \mathrm{P}$ ratings is the following. In the $\mathrm{S} \& \mathrm{P}$ rating, some major risks can be hidden when the overall risk is aggregated with pre-assigned weights, as in that case one weakness of a country can cancel out with another strength of the same country. As a result, rankings obtained with the optimal risk indices (i.e., capturing the riskiest variables for all emerging markets) produce major rank reversals when compared with the S\&P ratings (i.e., capturing an average perception of risk with the pre-assigned weights). In this case, an emerging country may have an average risk assignment with S\&P ratings (e.g., Hungary) but may have a higher risk with the optimal indices that capture the common weaknesses of all emerging markets. In this case, our risk indices are not correlated with the $\mathrm{S} \& \mathrm{P}$ ratings and are more prone to capture the riskiest variables in each sub-index. Table 9 offers the detailed relative ranking differences between the optimal overall risk and the S\&P ratings for 2008. There exist major relative rank reversals such as Hungary, whereas Thailand and China are relatively riskier with the optimal overall risk index when compared with the S\&P ratings. On the other hand, Nigeria and Turkey are relatively less risky when compared with the $\mathrm{S} \& \mathrm{P}$ rankings. Overall, for most countries we notice a change in their relative rankings when we compare the optimal risk index with the S\&P rankings.

Overall, although rating companies do not employ exact formulas for combining the scores to determine ratings and the weights are not optimally chosen, either across the sovereigns or over time, they arrive at rankings that are correlated with our optimal political risk index. However, rating agencies assign ratings to emerging countries that are mostly stable over time and they often change their ratings after the market's view in times of severe deterioration and/or improvement of sovereign creditworthiness.

Finally, we consider whether our optimal sovereign risk rankings are significantly correlated or not with the sovereign bond interest rate spreads, annual basis points over US Treasuries. Table 10 presents the Spearman rank correlation coefficients between the sovereign bond interest rate spreads and our optimal sub-index rankings. In the first panel of Table 10 we report the Spearman correlation coefficient between the sovereign bond interest rate spreads and the optimal economic, political, financial and overall risk. There are 17 countries which have overlapping data for all optimal indices among the 32 emerging countries. We find that our financial and overall risk indices are positively correlated with the sovereign bond interest rate spreads in 2008 at the $5 \%$ significance level. In the second panel of Table 10, we compute the Spearman coefficient between the sovereign bond interest rate spreads and each optimal risk index ranking separately in order to use more countries for the analysis. The results are similar to those of the correlation coefficients with the 17 common countries. Our political risk index is positively correlated with the sovereign bond interest rate spreads at the $10 \%$ significance level when more countries are used for the analysis. 
In conclusion, although our analysis employed annual data, still it is able to capture a large part of the information released by the sovereign bond spreads.

\section{Conclusion}

This paper uses stochastic dominance efficiency tests at any order for time dependent data. We study tests for stochastic dominance efficiency of a given index with respect to all possible indices constructed from a set of individual components. We proceed to test whether stochastic dominance efficiency justifies the use of the arbitrarily-weighted risk indices obtained by rating agencies for the sovereign risk assessment: economic, political and financial risks. The results from the empirical analysis indicate that equally weighting risk factors in each sub-index does not produce an optimal index in the SD efficiency sense. We can construct many alternative indices that dominate the equally weighted sub-index risk value and assign a riskier environment to each emerging market country. Moreover, we construct an overall risk index and the results show that the financial risk is the main contributor to the overall sovereign risk environment in emerging markets followed by economic and political risk.

The implications of these results are important. We propose the riskiest factors in economic, political and financial terms for emerging countries. Higher sovereign risk among emerging markets over time can be mainly attributed to financial factors and as such reducing overall risk for a particular country would imply improvements of this country's financial institutions. Secondly, an emerging market country should have high growth rates, export more and have a positive budget balance to be less subject to economic risk; decrease the level of corruption, have fair legal systems and improve its institutional effectiveness in order to reach a better political environment; increase liquidity and decrease banking sector risk to achieve a better financial institutional environment. We should mention that the upper and lower bounds of each index may change over time; therefore, we should mention that the weighting scheme assigned to each index may change over time. Moreover, there may be a major improvement and/or deterioration of risk factors in each sub-index over time for emerging countries. Furthermore, one may expect that there may be some other risk factors found to be important in the future not captured in the current analysis. Since the optimal weighting scheme in the construction of the each sub-index changes i) as the bounds change, ii) if there is major improvement or deterioration of some risk factors for emerging countries and iii) with the inclusion of some other risk factors in the analysis, the stochastic dominance efficiency of the optimal risk indices should be tested periodically.

As a further research, one could employ other consistent SD pairwise tests, like in Linton et al. (2005) and Gonzalo and Olmo (2010), to determine whether one year has riskier outcomes than another year and/or whether some risk indicators are riskier than others in a given year using a pairwise comparison. It is also possible to determine the riskiest time periods for emerging markets and further analyze the main factors that precipitated this high risk environment. 
Another possible extension is to employ SD efficiency tests to analyze shorter span data to obtain optimal weights in order to refine the forecast of future sovereign crises. Finally, our methodology could be fruitfully applied to other group of countries, and in particular to mature economies where the risk of sovereign debt crises has increased dramatically. 


\section{Appendix A: Simulating p-values}

\subsection{Block Bootstrap Methods}

Block bootstrap methods extend the nonparametric i.i.d. bootstrap to a time series context (see Barrett and Donald (2003) and Abadie (2002) for use of the nonparametric i.i.d. bootstrap in stochastic dominance tests). They are based on "blocking" arguments, in which data are divided into blocks and those, rather than individual data, are resampled in order to mimic the time dependent structure of the original data. We focus on the block bootstrap since we face moderate sample sizes in the empirical applications, and wish to exploit the full sample information.

Let $b, l$ denote integers such that $T=b l$. The non-overlapping rule (Carlstein (1986)) just asks the data to be divided into $b$ disjoint blocks, the $k$-th being $\boldsymbol{B}_{k}=\left(\boldsymbol{Y}_{(k-1) l+1}^{\prime}, \ldots, \boldsymbol{Y}_{k l}^{\prime}\right)^{\prime}$ with $k \in\{1, \ldots, b\}$. The block bootstrap method requires that we choose blocks $\boldsymbol{B}_{1}^{*}, \ldots, \boldsymbol{B}_{b}^{*}$ by resampling randomly, with replacement, from the set of non-overlapping blocks. If $\boldsymbol{B}_{i}^{*}=\left(\boldsymbol{Y}_{i 1}^{* \prime}, \ldots, \boldsymbol{Y}_{i l}^{* \prime}\right)^{\prime}$, a block bootstrap sample $\left\{\boldsymbol{Y}_{t}^{*} ; t=1, \ldots, T\right\}$ is made of $\left\{\boldsymbol{Y}_{11}^{*}, \ldots, \boldsymbol{Y}_{1 l}^{*}, \boldsymbol{Y}_{21}^{*}, \ldots, \boldsymbol{Y}_{2 l}^{*}, \ldots\right.$, $\left.\boldsymbol{Y}_{b 1}^{*}, \ldots, \boldsymbol{Y}_{b l}^{*}\right\}$ and we let $\hat{F}^{*}$ denote its empirical distribution.

Let us define $p_{j}^{*}:=P\left[S_{j}^{*}>\hat{S}_{j}\right]$, where $S_{j}^{*}$ is the test statistic corresponding to each bootstrap sample. Then the block bootstrap method is justified by the next statement (the proof is given by ST (2010)).

Proposition 1 Assuming that $\alpha<1 / 2$, a test for $S D E_{j}$ based on the rule:

$$
\text { " reject } H_{0}^{j} \quad \text { if } p_{j}^{*}<\alpha ",
$$

satisfies the following

$$
\begin{array}{ll}
\lim P\left[\text { reject } H_{0}^{j}\right] \leq \alpha & \text { if } H_{0}^{j} \text { is true } \\
\lim P\left[\text { reject } H_{0}^{j}\right]=1 & \text { if } H_{0}^{j} \text { is false. }
\end{array}
$$

In practice we need to use Monte Carlo methods to approximate the probability. The $p$-value is simply approximated by $\tilde{p}_{j}=\frac{1}{R} \sum_{r=1}^{R} \mathbb{I}\left\{\tilde{S}_{j, r}>\hat{S}_{j}\right\}$, where the averaging is made on $R$ replications. The replication number can be chosen to make the approximations as accurate as we desire given time and computer constraints. 


\section{References}

Abadie, A., 2002. Bootstrap Tests for Distributional Treatment Effects in Instrumental Variable Models. J. Am. Stat. Assoc. 97, 284-292.

Abiad, A., Ostry J.D., 2005. Primary Surpluses and Sustainable Debt Levels in Emerging Market Countries. IMF Policy Discussion Paper No. PDP/05/6.

Afonso, A., 2003. Understanding the determinants of sovereign debt ratings: evidence for the two leading agencies. J. Econ. Finance 27, 56-74.

Afonso, A., Furcieri, D. Gomes, P. , 2011. Sovereign credit ratings and financial markets linkages. Application to European data. ECB Working Paper 1347, 1-43.

Afonso, A., Gomes, P., Rother, P., 2011. Short-and long-run determinants of sovereign debt credit ratings. Int. J. Finance Econ. 16, 1-15.

Albuquerque, P.H., 2005. Optimal time interval selection in long-run correlation estimation, Econometrics 0511017, EconWPA

Anderson, G., 1996. Nonparametric tests of stochastic dominance in income distributions. Econometrica 64, 1183-1193.

Baek, I., Bandopadhyaya, A., Du, C., 2005. Determinants of market-assessed sovereign risk: economic fundamentals or market risk appetite? J. Int. Money Finance 24, 533-548.

Barrett, G., Donald, S., 2003. Consistent tests for stochastic dominance. Econometrica 71, 71-104.

Beach, C., Davidson, R., 1983. Distribution-free statistical inference with Lorenz curves and income shares. Rev. Econ. Stud. 50, 723-735.

Bulow, J., Rogoff, K., 1989. Sovereign debt: is to forgive or to forget? Am. Econ. Rev. 79, 43-50.

Cantor, R., Packer, F., 1996a. Determinants and impact of sovereign credit ratings. Fed. Reserve Bank New York Econ. Pol. Rev. Issue Oct., 37-53.

Cantor, R., Packer, F., 1996b. Sovereign risk assessment and agency credit ratings. Europ. Finan. Manage. 2, 247-256.

Carlstein, E., 1986. The Use of Subseries Methods for Estimating the Variance of a General Statistic From a Stationary Time Series. Ann. Stat. 14, 1171-1179.

Catao, L., Kapur, S., 2004. Missing Link: Volatility and the Debt Intolerance Paradox. IMF Working Paper 04/51.

Catao, L., Sutton, B., 2002. Sovereign Defaults: the Role of Volatility. IMF Working Paper 02/149.

Chen, Y., Rogoff, K., 2003. Commodity currencies. J. Int. Econ. 60, 133-160.

Davidson, R., Duclos, J.-Y., 2000. Statistical inference for stochastic dominance and for the measurement of poverty and inequality. Econometrica 68, 1435-1464.

Eichengreen, B., Hausmann, R., 2005. Other People's Money - Debt Denomination and Financial Instability in Emerging Market Economies. University of Chicago Press, Chicago. 
Eichengreen, B., Mody, A., 1998. What explains changing spreads on emergingmarket debt: Fundamentals or Market Sentiment? NBER Working Paper 6408.

Erb, C. B., Harvey, R. C., Viskanta, T.E., 1996. Political risk, economic risk, and financial risk. Finan. Analyst J. 52, 28-46.

Erb, C. B., Harvey, R. C., Viskanta, T.E., 1999. New perspectives on emerging market bonds: looking beyond the current crisis. J. Portfol. Manage. 25, 83-92.

Ferri, G., Liu, L.-G., Stiglitz, J.E., 1999. The procyclical role of rating agencies: evidence from the East Asian crisis. Econ. Notes 28, 335-355.

Flandreau, M., Gaillard, N., Packer, F., 2009. Rating Performance, Regulation and the Great Depression: Lessons from Foreign Government Securities. CEPR Working Paper 7328.

Gaillard, N., 2007. Fitch, Moody's and S\&P's Sovereign Ratings and EMBI Global Spreads: Lessons from 1993-2007. Working Paper, Science PO, Institut d'Etudes Politiques de Paris.

Gapen, M., Gray, D., Lim, C., Xiao Y., 2005. Measuring and Analyzing Sovereign Risk with Contingent Claims. IMF Working Paper 05/155.

Gonzalo, J., Olmo J., 2010. Conditional stochastic dominance tests in dynamic settings, Working Paper, we1029, Universidad Carlos III, Departamento de Economía.

Gray, D., Malone, S., 2008. Macrofinancial Risk Analysis. J. Wiley \& Sons Inc. Chichester, West Sussex, England.

Gray, D., Merton, R., Bodie, Z., 2006. A new framework for analyzing and managing macrofinancial risks of an economy. NBER Working Paper 12637.

Hausmann, R., Panizza U., 2003. On the determinants of original sin: an empirical investigation. J. Int. Money Finance 22, 957-990.

Hilscher, J., Nosbusch, Y. 2010. Determinants of sovereign risk: macroeconomic fundamentals and the pricing of sovereign debt. Rev. Finance 14, 235-262.

Hui, H., Lo, F., 2002. Valuation model of defaultable bond values in emerging markets. Asia-Pacific Finan. Mark. 9, 45-60.

IMF Country Report, various years various countries

Ismailescu, J., Kazemi, H., 2010. The reaction of emerging market credit default swap spreads to sovereign credit rating changes. J. Banking Finance 34, 2861-2873.

Jeanne, O., 2003. Why do emerging market economies borrow in foreign currency. IMF Working Paper 03/177.

Kruger, M., Messmacher, M., 2004. Sovereign Debt Defaults and Financing Needs. IMF Working Paper 04/53.

Linton, O., Maasoumi, E., Whang, Y.-J., 2005. Consistent testing for stochastic dominance under general sampling schemes. Rev. Econ. Stud. 72, 735-765.

Mendoza, E., 1995. The terms of trade, the real exchange rate and economic fluctuations. Int. Econ. Rev. 36, 101-137.

Min, H., 1998. Determinants of Emerging Market Bond Spread: Do Economic Fundamentals Matter? World Bank Policy Research Working Paper No. 
WPS 1899, World Bank, Washington, DC

Pinar, M., Stengos, T., Topaloglou, N., 2012. Measuring human development: a stochastic dominance approach. University of Guelph, manuscript.

Reinhart, C.M., 2002. Default, Currency Crises and Sovereign Credit Ratings. NBER Working Paper 8738.

Reinhart, C.M., Rogoff, K. S., Savastano, M.A., 2003. Debt Intolerance. Brookings Pap. Econ. Act. 1, 1-74.

Rio, E., 2000. Theorie Asymptotique des Processus Aleatoires Faiblement Dependants. Mathematiques et Applications, 31. Springer-Verlag, Berlin.

Scaillet, O., Topaloglou, N., 2010. Testing for stochastic dominance efficiency. J. Bus. Econ. Stat. 28, 169-180.

Standard \& Poor's, Sovereign Credit Ratings: A Primer, various years.

Sturzenegger, F., Zettelmeyer, J., 2006. Debt Defaults and Lessons from a Decade of Crises. The MIT Press, Cambridge Massachusetts.

Sy, A., 2001. Emerging Market Bond Spreads and Sovereign Credit Ratings: Reconciling Market Views with Economic Fundamentals. IMF Working Paper $01 / 165$.

Van Rijckeghem, C., and Weder, B., 2004. The Politics of Debt Crises. CEPR Discussion Paper 4683.

Zettelmeyer, J., and Jeanne, O., 2002. Original Sin, Balance Sheet Crises and the Role of International Lending. IMF Working Paper 02/234. 


\begin{tabular}{|c|c|c|}
\hline INDEX & Methodology & \\
\hline ICRG & $\begin{array}{l}3 \text { sub-indices } \mathrm{P}, \mathrm{F}, \mathrm{E} \text { and a composite index } \mathrm{C} \text {. } \\
\text { Political risk index } \mathrm{P} \text { (based on } 100 \text { points), financial risk (based on } \\
50 \text { points) and economic risk } \mathrm{E} \text { (based on } 50 \text { points). } \\
\qquad \mathrm{C}=(\mathrm{P}+\mathrm{F}+\mathrm{E}) / 2 \\
\text { The composite index ranges from } 0 \text { to } 100 \text { : the interval } 0-49.9 \\
\text { corresponds to very high risk, the interval } 80-100 \text { to very low risk. }\end{array}$ & http://www.prsgroup.com \\
\hline II & $\begin{array}{l}\text { Country creditworthiness scores are based on ratings provided by a } \\
\text { survey of leading international bankers who are asked to grade each } \\
\text { of the countries on a scale from } 0 \text { to } 100 \text {, where } 0 \text { represents the } \\
\text { least creditworthy country. The answers are weighted following an } \\
\text { unpublished formula that "properly gives more weights to responses } \\
\text { from banks with the largest worldwide exposure and the most } \\
\text { sophisticated country analysis systems". }\end{array}$ & http://www.institutionalinvestor.com \\
\hline Euromoney & $\begin{array}{l}\text { A panel of several leading experts (economists and political } \\
\text { analysts) are asked to rate each country for which they have } \\
\text { knowledge. The credit rating score assigned to each country is a } \\
\text { weighted average of seven indicators: political risk }(30 \%) \text {, } \\
\text { economic performance }(30 \%) \text { access to bank finance/capital } \\
\text { markets }(10 \%) \text {, discount on forfeiting }(10 \%) \text {, credit ratings }(7.5 \%) \\
\text { assigned from the major rating agencies, debt indicators }(7.5 \%) \text { and } \\
\text { debt in default or rescheduled }(5 \%) \text { calculated from the World } \\
\text { Bank's Global Development Finance figures. }\end{array}$ & http://www.euromoneycountryrisk.com \\
\hline EIU & $\begin{array}{l}\text { Based on } 7 \text {-year historical data sequence, it considers a large set of } \\
\text { variables (e.g. current account balance, financial requirements, } \\
\text { foreign reserves, short-term debt, vulnerability of the banking } \\
\text { sector) for a large set of countries and, in particular, emerging and } \\
\text { highly indebted countries. }\end{array}$ & http://www.eiu.com \\
\hline BERI & $\begin{array}{l}\text { It employs structured qualitative methods, i.e., standardized formats } \\
\text { with specifically stipulated scope and focus of analysis across } \\
\text { countries. Three main determinants: business climate, political } \\
\text { stability, currency and repayment risk. Two risk indices are } \\
\text { calculated three times a year: ORI (operations risk index) and PRI } \\
\text { (political risk index). A great emphasis is given to PRI, whose main } \\
\text { components are linguistic/ethnic/religious tensions, corruption, } \\
\text { nepotism, social conditions, social conflict, income distribution, } \\
\text { history of regime instability, etc. }\end{array}$ & http://www.beri.com \\
\hline
\end{tabular}

Figure 1: Country risk indices 


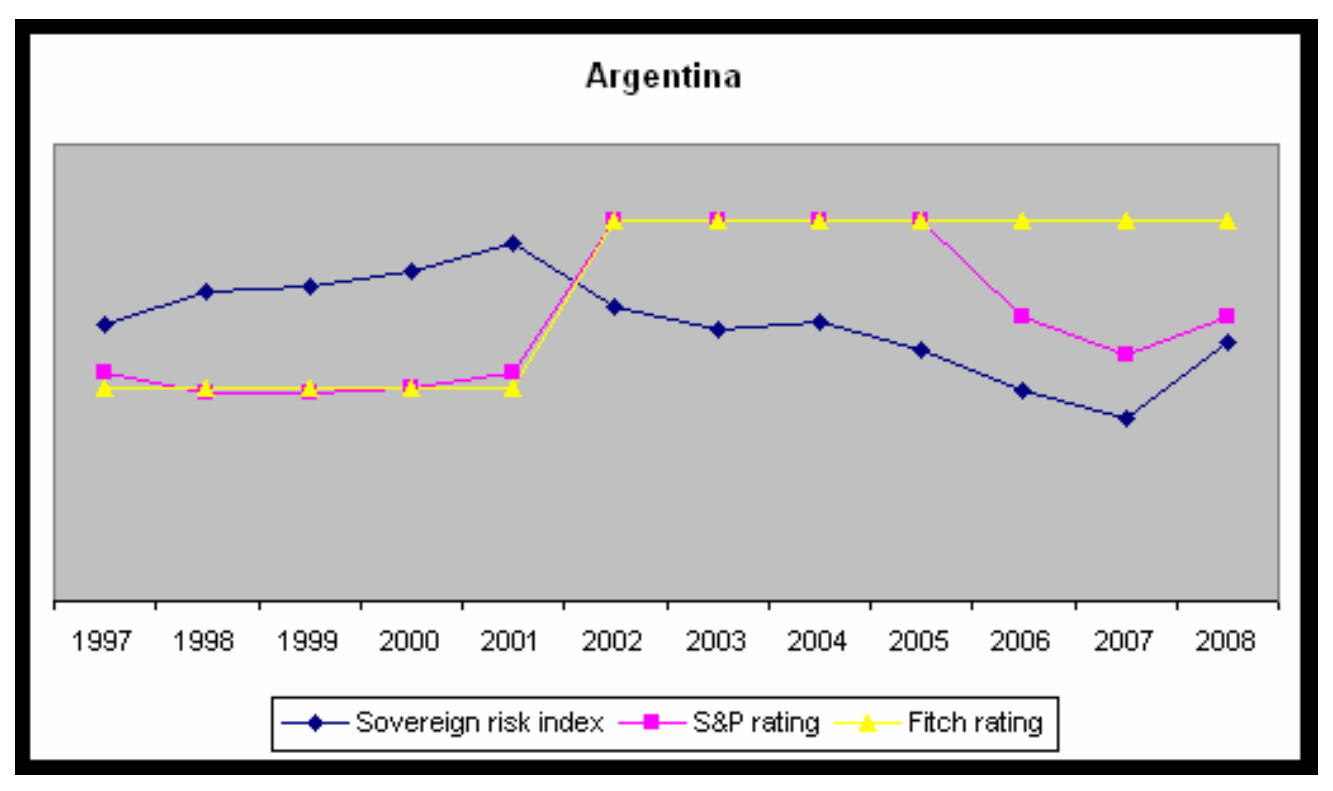

Figure 2: Sovereign risk index for Argentina 
Table 1

Data descriptions and sources

\begin{tabular}{|c|c|}
\hline Variable & Definition and/or sources \\
\hline \multicolumn{2}{|l|}{ Economic risk factors } \\
\hline $\begin{array}{l}\text { Budget balance } \\
\text { (\% of GDP) }\end{array}$ & $\begin{array}{l}\text { Central government receipts minus central government outlays, as a percentage of GDP. } \\
\text { Derived from National sources. }\end{array}$ \\
\hline $\begin{array}{l}\text { Current Account } \\
\text { Balance/GDP }\end{array}$ & Current-account balance as a percentage of GDP. Derived from lines 78ald and 99b in the IFS. \\
\hline Total Debt/GDP & Total external debt at end-period as a percentage of nominal GDP. Derived from IFS. \\
\hline Public Debt (\% of GDP) & $\begin{array}{l}\text { Total debt after consolidation (both local and foreign currency) owed by central government to } \\
\text { domestic residents, foreign nationals and multilateral institutions such as the IMF, expressed as a } \\
\text { percentage of GDP. }\end{array}$ \\
\hline Terms of trade $(1990=100)$ & Ratio of the export price index to the import price index $(1990=100)$. Derived from IFS. \\
\hline GDP (\% real change) & Percentage change in real GDP, over previous year. \\
\hline $\begin{array}{l}\text { Consumer prices } \\
(\% \text { change })\end{array}$ & Percentage change in consumer price index in local currency (period average), over previous year. \\
\hline Total debt per head & Total external debt divided by population (line $99 \mathrm{z}$ in the IFS). \\
\hline Effective maturity & $\begin{array}{l}\text { Total medium- and long-term debt in the previous year divided by medium- and long-term } \\
\text { principal repayments paid for the current year expressed in years. }\end{array}$ \\
\hline \multicolumn{2}{|l|}{ Political risk factors } \\
\hline $\begin{array}{l}\text { EIU political environment } \\
\text { rating (PERT) }\end{array}$ & $\begin{array}{l}\text { The political environment rating scores countries between } 1 \text { and } 10 \text { on political stability and } \\
\text { institutional effectiveness, with } 1 \text { being low and } 10 \text { being high. }\end{array}$ \\
\hline $\begin{array}{l}\text { EIU policy environment for } \\
\text { foreign investment rating } \\
\text { (FIRT) }\end{array}$ & $\begin{array}{l}\text { The EIU's policy towards foreign investment rating scores countries between } 1 \text { and } 10 \text { on a variety } \\
\text { of measures including government policy and the risk of expropriation, with } 1 \text { being low and } 10 \\
\text { being high. }\end{array}$ \\
\hline $\begin{array}{l}\text { EIU political stability } \\
\text { rating (PSER) }\end{array}$ & $\begin{array}{l}\text { The political stability rating scores countries between } 1 \text { and 10, with } 1 \text { being low and } 10 \text { being } \\
\text { high. }\end{array}$ \\
\hline $\begin{array}{l}\text { EIU institutional } \\
\text { effectiveness rating (IEER) }\end{array}$ & $\begin{array}{l}\text { The institutional effectiveness rating scores countries between } 1 \text { and 10, with } 1 \text { being low and } 10 \\
\text { being high. }\end{array}$ \\
\hline $\begin{array}{l}\text { Risk of armed conflict } \\
\text { (ACER) }\end{array}$ & $\begin{array}{l}\text { The risk of armed conflict rating scores countries between } 1 \text { and } 5 \text {, with } 1 \text { being very high and } 5 \\
\text { being very low. }\end{array}$ \\
\hline $\begin{array}{l}\text { Risk of social unrest } \\
\text { (SUER) }\end{array}$ & $\begin{array}{l}\text { The risk of social unrest rating scores countries between } 1 \text { and } 5 \text {, with } 1 \text { being very high and } 5 \\
\text { being very low. }\end{array}$ \\
\hline Terrorism threat (TRER) & $\begin{array}{l}\text { The EIU's terrorism threat rating scores countries between } 1 \text { and } 5 \text { on the terrorist threat to } \\
\text { government and business, with } 1 \text { being very high and } 5 \text { being no threat. }\end{array}$ \\
\hline $\begin{array}{l}\text { International disputes and } \\
\text { tensions (IDER) }\end{array}$ & $\begin{array}{l}\text { The EIU's international disputes and tensions rating scores countries between } 1 \text { and } 5 \text { on the threat } \\
\text { posed by international disputes to the economy and polity, with } 1 \text { being very high and } 5 \text { being no } \\
\text { threat. }\end{array}$ \\
\hline $\begin{array}{l}\text { Government stance towards } \\
\text { business (GBER) }\end{array}$ & $\begin{array}{l}\text { The EIU's government stance towards business rating scores countries between } 1 \text { and } 5 \text { on the } \\
\text { likelihood that the current government will implement open, liberal, and pro-business policies, } \\
\text { with } 1 \text { being very low and } 5 \text { being very high. }\end{array}$ \\
\hline $\begin{array}{l}\text { Effectiveness of system in } \\
\text { policy implementation } \\
\text { (PIER) }\end{array}$ & $\begin{array}{l}\text { The EIU's business environment rankings quantify the attractiveness of the business environment. } \\
\text { The effectiveness of policy implementation and execution rating scores countries between } 1 \text { and } 5 \text {, } \\
\text { with } 1 \text { being very low and } 5 \text { being very high. }\end{array}$ \\
\hline $\begin{array}{l}\text { Quality of bureaucracy } \\
\text { (QBER) }\end{array}$ & $\begin{array}{l}\text { The EIU's business environment rankings quantify the attractiveness of the business environment. } \\
\text { The quality of bureaucracy rating scores countries between } 1 \text { and } 5 \text {, with } 1 \text { being very low and } 5 \\
\text { being very high. }\end{array}$ \\
\hline $\begin{array}{l}\text { Transparency and fairness } \\
\text { of legal system (ROFL) }\end{array}$ & $\begin{array}{l}\text { The EIU's government stance towards business rating scores countries between } 1 \text { and } 5 \text { on the } \\
\text { transparency and fairness of legal system, with } 1 \text { being very low/unfair and } 5 \text { being very high/fair. }\end{array}$ \\
\hline $\begin{array}{l}\text { Level of corruption } \\
\text { (CRER) }\end{array}$ & $\begin{array}{l}\text { The EIU's corruption rating scores countries between } 1 \text { and } 5 \text { on the pervasiveness of corruption } \\
\text { among public officials, with } 1 \text { being very high and } 5 \text { being very low. }\end{array}$ \\
\hline Impact of crime (ICER) & $\begin{array}{l}\text { The EIU's impact of crime rating scores countries between } 1 \text { and } 5 \text { on whether violent crime is a } \\
\text { problem for government and business, with } 1 \text { being strongly yes and } 5 \text { being strongly no. }\end{array}$ \\
\hline $\begin{array}{l}\text { Degree of property rights } \\
\text { protection (PRRT) }\end{array}$ & $\begin{array}{l}\text { The EIU's business environment rankings quantify the attractiveness of the business environment. } \\
\text { The degree of property rights protection rating scores countries between } 1 \text { and } 5 \text {, with } 1 \text { being very } \\
\text { low and } 5 \text { being very high. }\end{array}$ \\
\hline $\begin{array}{l}\text { Fairness of tax system } \\
\text { (TSER) }\end{array}$ & $\begin{array}{l}\text { The EIU's business environment rankings quantify the attractiveness of the business environment. } \\
\text { The fairness of tax system rating scores countries between } 1 \text { and } 5 \text {, with } 1 \text { being very low and } 5 \\
\text { being very high. }\end{array}$ \\
\hline
\end{tabular}


Table 1 (continued)

\begin{tabular}{|l|l|}
\hline Variable & Definition and/or sources \\
\hline Financial risk factors & \\
\hline Banking Sector risk & $\begin{array}{l}\text { The EIU's banking sector risk rakings quantify a score given to assess whether there are likely to } \\
\text { be payment problems within the banking sector. The banking sector risk scores countries between } \\
0 \text { and 100, with 0 being very low and 100 being very high. }\end{array}$ \\
\hline Stock market index & Composite stock market index (12/31/92=100) in local currency. \\
\hline Lending interest rate & $\begin{array}{l}\text { Commercial banks average lending rate to non-financial enterprises (all loans exc current } \\
\text { accounts) }\end{array}$ \\
\hline Money market interest rate & Weighted average yield on 13 week Treasury bills. \\
\hline Loans/assets & $\begin{array}{l}\text { This liquidity ratio indicates what percentage of the assets of the bank are tied up in loans. The } \\
\text { higher this ratio the less liquid the banking system will be. }\end{array}$ \\
\hline $\begin{array}{l}\text { Increase in interest arrears } \\
\text { (if any) }\end{array}$ & $\begin{array}{l}\text { Change in cumulative stock of unpaid interest charges due on long-term external debt at end- } \\
\text { period. }\end{array}$ \\
\hline $\begin{array}{l}\text { Increase in principal arrears } \\
\text { (if any) }\end{array}$ & $\begin{array}{l}\text { Change in cumulative stock of overdue principal repayments on long-term external debt at end- } \\
\text { period. }\end{array}$ \\
\hline Percentage change in M1 & $\begin{array}{l}\text { Percentage change in total supply of notes and coins plus demand deposits at end-period, over } \\
\text { previous year. Derived from line 34 in IFS }\end{array}$ \\
\hline Percentage change in M2 & $\begin{array}{l}\text { Percentage change in M1 plus quasi-money at end-period, over previous year. Derived directly } \\
\text { from lines 34 and 35 in IFS. }\end{array}$ \\
\hline
\end{tabular}


Table 2A

Data and Descriptive Statistics (Normalized to unit range)

\begin{tabular}{|l|c|l|c|c|c|c|c|c|c|}
\hline Normalized economic risk factors & $\begin{array}{l}\text { Current } \\
\text { Account } \\
\text { Balance } \\
\text { (\% of GDP) } \\
\text { Balance/GDP }\end{array}$ & $\begin{array}{l}\text { Total } \\
\text { Debt/GDP }\end{array}$ & $\begin{array}{l}\text { Public Debt } \\
\text { (\% of GDP) }\end{array}$ & $\begin{array}{l}\text { Terms of } \\
\text { Trade } \\
(1990=100)\end{array}$ & $\begin{array}{l}\text { GDP } \\
\text { (\% real } \\
\text { change })\end{array}$ & $\begin{array}{l}\text { Consumer } \\
\text { prices } \\
(\% \text { change })\end{array}$ & $\begin{array}{l}\text { Total Debt } \\
\text { per head }\end{array}$ & $\begin{array}{l}\text { Effective } \\
\text { Maturity }\end{array}$ \\
\hline Mean & 0.475 & 0.429 & 0.284 & 0.142 & 0.814 & 0.456 & 0.060 & 0.084 & 0.142 \\
\hline Median & 0.467 & 0.445 & 0.259 & 0.134 & 0.840 & 0.434 & 0.048 & 0.063 & 0.093 \\
\hline Std. Dev. & 0.139 & 0.134 & 0.175 & 0.091 & 0.127 & 0.143 & 0.063 & 0.109 & 0.139 \\
\hline Min & 0 & 0 & 0 & 0 & 0 & 0 & 0 & 0 & 0 \\
\hline Max & 1 & 1 & 1 & 1 & 1 & 1 & 1 & 1 \\
\hline
\end{tabular}

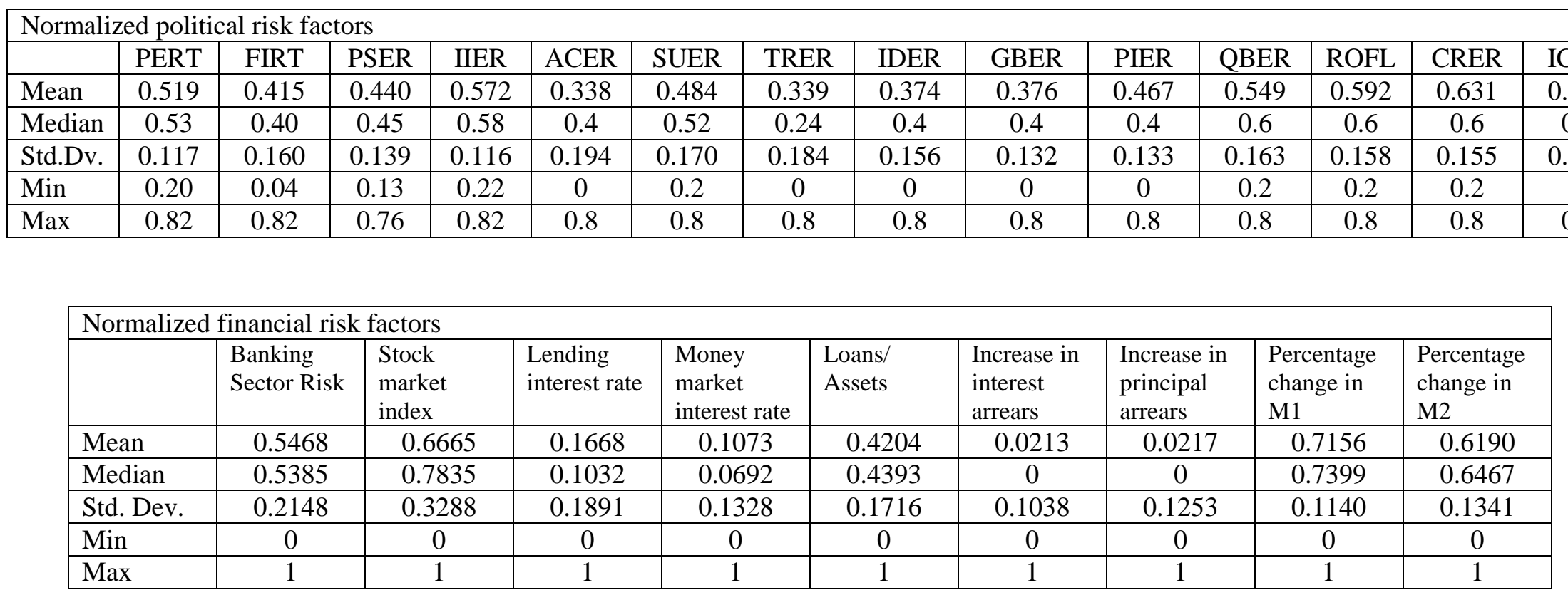




\section{Table 2B}

Data and Descriptive Statistics (Before normalization to unit range)

\begin{tabular}{|l|l|l|l|c|c|c|c|c|c|}
\hline Economic risk factors & $\begin{array}{l}\text { Budget } \\
\text { Balance } \\
(\% \text { of GDP) }\end{array}$ & $\begin{array}{l}\text { Current } \\
\text { Account } \\
\text { Balance/GDP }\end{array}$ & $\begin{array}{l}\text { Total } \\
\text { Debt/GDP }\end{array}$ & $\begin{array}{l}\text { Public Debt } \\
\text { (\% of GDP })\end{array}$ & $\begin{array}{l}\text { Terms of } \\
\text { Trade } \\
(1990=100)\end{array}$ & $\begin{array}{l}\text { GDP } \\
(\% \text { real } \\
\text { change })\end{array}$ & $\begin{array}{l}\text { Consumer } \\
\text { prices } \\
(\% \text { change })\end{array}$ & $\begin{array}{l}\text { Total Debt } \\
\text { per head }\end{array}$ & $\begin{array}{l}\text { Effective } \\
\text { Maturity }\end{array}$ \\
\hline Mean & -2.585 & -0.518 & 42.201 & 46.406 & 114.692 & 3.952 & 20.563 & 0.001 & 11.342 \\
\hline Median & -2.401 & -1.204 & 38.729 & 43.853 & 103.967 & 4.663 & 7.461 & 0.001 & 7.8 \\
\hline Std. Dev. & 3.344 & 5.794 & 25.133 & 26.96 & 53.925 & 4.481 & 69.933 & 0.002 & 9.867 \\
\hline Min & -15.211 & -25.2 & 1.587 & 4.108 & 36.025 & -13.128 & -45.511 & 0.000 & 1.212 \\
\hline Max & 8.819 & 18.035 & 144.844 & 301.531 & 459.6 & 18.287 & 1058.374 & 0.017 & 72.337 \\
\hline
\end{tabular}

\begin{tabular}{|c|c|c|c|c|c|c|c|c|c|c|c|c|c|c|c|c|}
\hline \multicolumn{17}{|c|}{ Political risk factors } \\
\hline & PERT & FIRT & PSER & IIER & ACER & SUER & TRER & IDER & GBER & PIER & QBER & ROFL & CRER & ICER & PRRT & TSER \\
\hline Mean & 4.808 & 5.846 & 5.601 & 4.278 & 3.312 & 2.583 & 3.304 & 3.132 & 3.119 & 2.665 & 2.255 & 2.039 & 1.844 & 2.701 & 3.218 & 2.329 \\
\hline Median & 4.7 & 6 & 5.5 & 4.2 & 3 & 2.4 & 3.8 & 3 & 3 & 3 & 2 & 2 & 2 & 3 & 3 & 2 \\
\hline Std.Dv. & 1.172 & 1.598 & 1.388 & 1.157 & 0.971 & 0.851 & 0.919 & 0.779 & 0.658 & 0.664 & 0.816 & 0.791 & 0.775 & 0.794 & 0.980 & 0.758 \\
\hline Min & 1.8 & 1.8 & 2.4 & 1.8 & 1 & 1 & 1 & 1 & 1 & 1 & 1 & 1 & 1 & 1 & 1 & 1 \\
\hline Max & 8 & 9.6 & 8.7 & 7.8 & 5 & 4 & 5 & 5 & 5 & 5 & 4 & 4 & 4 & 5 & 5 & 4 \\
\hline
\end{tabular}

\begin{tabular}{|l|l|l|l|c|c|l|l|l|}
\hline Financial risk factors & $\begin{array}{l}\text { Banking Sector } \\
\text { Risk }\end{array}$ & $\begin{array}{l}\text { Lending } \\
\text { interest rate }\end{array}$ & $\begin{array}{l}\text { Money market } \\
\text { interest rate }\end{array}$ & Loans/ Assets & $\begin{array}{l}\text { Increase in } \\
\text { interest arrears }\end{array}$ & $\begin{array}{l}\text { Increase in } \\
\text { principal } \\
\text { arrears }\end{array}$ & $\begin{array}{l}\text { Percentage } \\
\text { change in M1 }\end{array}$ & $\begin{array}{l}\text { Percentage } \\
\text { change in M2 }\end{array}$ \\
\hline Mean & 52.431 & 18.736 & 10.936 & 50.399 & 146.364 & 213.492 & 21.389 & 20.393 \\
\hline Median & 52 & 12.92 & 7.504 & 51.845 & 0 & 0 & 17.026 & 16.751 \\
\hline Std. Dev. & 11.169 & 17.307 & 12.046 & 13.092 & 711.656 & 1232.88 & 20.474 & 17.683 \\
\hline Min & 24 & 3.47 & 1.229 & 18.318 & 0 & 0 & -29.674 & -29.824 \\
\hline Max & 76 & 95 & 91.954 & 94.634 & 6855.7 & 9840.9 & 149.852 & 101.991 \\
\hline
\end{tabular}


Table 3

Unit root tests

\begin{tabular}{|c|c|c|c|}
\hline Economic Risk Indices & Index levels (SBIC) & Index levels (AIC) & Index levels (HQIC) \\
\hline Budget Balance & $-4.024 *$ & $-4.024 *$ & $-4.024 *$ \\
\hline Current Account Balance & $-22.036 *$ & $-4.767 *$ & $-6.038^{*}$ \\
\hline Total Debt & $-23.311 *$ & -3.729 & $-4.024 *$ \\
\hline Public Debt & $-20.105^{*}$ & $-4.073 *$ & $-4.423 *$ \\
\hline Terms of Trade & $-3.158 * *$ & $-3.158 * *$ & $-3.158 * *$ \\
\hline GDP & $-4.463 *$ & $-4.463 *$ & $-4.463 *$ \\
\hline Consumer Prices & $-19.382 *$ & $-14.083 *$ & $-14.083 *$ \\
\hline Total Debt per capita & $-6.190 *$ & $-5.285^{*}$ & $-6.190 *$ \\
\hline Effective Maturity & $-21.892 *$ & $-9.411^{*}$ & $-21.892 *$ \\
\hline \multicolumn{4}{|l|}{ Political Risk Indices } \\
\hline PERT & $-7.225^{*}$ & $-6.389 *$ & $-6.299 *$ \\
\hline FIRT & $-6.303 *$ & $-6.303 *$ & $-6.303^{*}$ \\
\hline PSER & $-7.445^{*}$ & $-7.445^{*}$ & $-7.445^{*}$ \\
\hline ACER & $-9.757 *$ & $-9.757 *$ & $-9.757 *$ \\
\hline SUER & $-13.321 *$ & $-7.581 *$ & $-13.321 *$ \\
\hline TRER & $-6.358 *$ & $-6.357 *$ & $-6.358 *$ \\
\hline IDER & $-11.481 *$ & $-11.481 *$ & $-11.481 *$ \\
\hline IEER & $-11.090 *$ & $-9.621 *$ & $-9.621 *$ \\
\hline GBER & $-11.794 *$ & $-11.794 *$ & $-11.794 *$ \\
\hline PIER & $-6.162 *$ & $-6.162 *$ & $-6.162 *$ \\
\hline QBER & $-8.341 *$ & $-8.341 *$ & $-8.341 *$ \\
\hline ROFL & $-13.830 *$ & $-13.830 *$ & $-13.830 *$ \\
\hline CRER & $-11.624 *$ & $-11.624 *$ & $-11.624 *$ \\
\hline ICER & $-5.838 *$ & $-5.838^{*}$ & $-5.838 *$ \\
\hline PRRT & $-9.672 *$ & $-9.696^{*}$ & $-9.672 *$ \\
\hline TSER & $-6.414 *$ & $-6.414 *$ & $-6.414 *$ \\
\hline \multicolumn{4}{|l|}{ Financial Risk Indices } \\
\hline Banking Sector & $-5.773 *$ & $-4.265^{*}$ & $-5.773 *$ \\
\hline Stock Market & $-9.331 *$ & $-6.772 *$ & $-8.003 *$ \\
\hline Lending interest rate & $-14.965^{*}$ & $-4.987^{*}$ & $-4.692 *$ \\
\hline Money market interest rate & $-6.279 *$ & $-5.303 *$ & $-5.303 *$ \\
\hline Loan/Assets & $-15.886^{*}$ & $-9.482 *$ & $-9.482 *$ \\
\hline Increase in interest arrears & $-15.767 *$ & $-15.767 *$ & $-15.767 *$ \\
\hline Increase in principal arrears & $-15.540 *$ & $-15.540 *$ & $-15.540 *$ \\
\hline Change in M1 & $-14.601 *$ & $-14.601 *$ & $-14.601 *$ \\
\hline Change in M2 & $-16.363^{*}$ & $-16.363^{*}$ & $-16.363^{*}$ \\
\hline \multicolumn{4}{|c|}{$\begin{array}{l}\text { Notes: Critical values of ADF are } 1 \%(-3.44) \text { and } 5 \%(-2.86) \text {, respectively, taken from MacKinnon (1991). } \\
\text { ADF lag length decision based on Schwartz information criterion (SBIC), Akaike's information criterion } \\
\text { (AIC), and the Hannan and Quinn information criterion (HQIC) (minimum lag }=0 \text { and maximum lag }=10 \text { ) } \\
* \text {, and ** indicates significance at the } 1 \%, 5 \% \text { level of rejecting the unit root process. The null hypothesis is } \\
\text { that the variable suggests a unit root process and the alternative is that the variable is generated by a } \\
\text { stationary process. }\end{array}$} \\
\hline
\end{tabular}




\section{Table 4}

Stochastic efficient weighting for economic, political and financial risk

\begin{tabular}{|c|c|c|c|c|c|c|c|c|c|c|}
\hline \multicolumn{11}{|c|}{ Stochastic efficient weighting for economic risk } \\
\hline $\begin{array}{l}\text { Number of } \\
\text { observations }\end{array}$ & $\begin{array}{l}\text { Number of } \\
\text { dominating } \\
\text { weighting } \\
\text { scheme }\end{array}$ & $\begin{array}{l}\text { Budget } \\
\text { Balance } \\
(\% \text { of } \\
\text { GDP })\end{array}$ & $\begin{array}{l}\text { Current } \\
\text { Account } \\
\text { Balance/GDP }\end{array}$ & $\begin{array}{l}\text { Total } \\
\text { Debt/GDP }\end{array}$ & $\begin{array}{l}\text { Public } \\
\text { Debt } \\
\text { (\% of } \\
\text { GDP) } \\
\end{array}$ & $\begin{array}{l}\text { Terms of } \\
\text { Trade } \\
(1990=100)\end{array}$ & $\begin{array}{l}\text { GDP } \\
\text { (\% real } \\
\text { change) }\end{array}$ & $\begin{array}{l}\text { Consumer } \\
\text { prices } \\
(\% \\
\text { change }) \\
\end{array}$ & $\begin{array}{l}\text { Total } \\
\text { Debt } \\
\text { per } \\
\text { head }\end{array}$ & $\begin{array}{l}\text { Effective } \\
\text { Maturity }\end{array}$ \\
\hline $\mathrm{N}$ & $\mathrm{n}$ & \multicolumn{9}{|c|}{ Average of dominating weighting schemes } \\
\hline 454 & 450 & 0.157 & 0.002 & 0.000 & 0.000 & 0.315 & 0.521 & 0.000 & 0.005 & 0.000 \\
\hline
\end{tabular}

\begin{tabular}{|c|c|c|c|c|c|c|c|c|c|c|c|c|c|c|c|}
\hline \multicolumn{16}{|c|}{ Stochastic efficient weighting for political risk } \\
\hline PERT & FIRT & PSER & IEER & ACER & SUER & TRER & IDER & GBER & PIER & QBER & ROFL & CRER & ICER & PRRT & TSER \\
\hline \multicolumn{16}{|c|}{ Average of dominating weighting schemes } \\
\hline 0.000 & 0.000 & 0.000 & 0.152 & 0.000 & 0.003 & 0.001 & 0.000 & 0.001 & 0.000 & 0.022 & 0.332 & 0.381 & 0.093 & 0.013 & 0.002 \\
\hline
\end{tabular}

\begin{tabular}{|c|c|c|c|c|c|c|c|c|c|c|}
\hline \multicolumn{11}{|c|}{ Stochastic efficient weighting for financial and banking sector risk } \\
\hline $\begin{array}{l}\text { Number of } \\
\text { observations }\end{array}$ & $\begin{array}{l}\text { Number of } \\
\text { dominating } \\
\text { weighting } \\
\text { schemes }\end{array}$ & $\begin{array}{l}\text { Banking } \\
\text { Sector } \\
\text { Risk }\end{array}$ & $\begin{array}{l}\text { Stock } \\
\text { Market } \\
\text { Index }\end{array}$ & $\begin{array}{l}\text { Lending } \\
\text { interest } \\
\text { rate }\end{array}$ & $\begin{array}{l}\text { Money } \\
\text { market } \\
\text { interest } \\
\text { rate }\end{array}$ & $\begin{array}{l}\text { Loans/ } \\
\text { Assets }\end{array}$ & $\begin{array}{l}\text { Increase } \\
\text { in } \\
\text { interest } \\
\text { arrears }\end{array}$ & $\begin{array}{l}\text { Increase } \\
\text { in } \\
\text { principal } \\
\text { arrears }\end{array}$ & $\begin{array}{l}\% \\
\text { change } \\
\text { in M1 }\end{array}$ & $\begin{array}{l}\% \\
\text { change } \\
\text { in M2 }\end{array}$ \\
\hline $\mathrm{N}$ & $\mathrm{n}$ & \multicolumn{9}{|c|}{ Average of dominating weighting schemes } \\
\hline 232 & 232 & 0.344 & 0.160 & 0.000 & 0.000 & 0.046 & 0.000 & 0.000 & 0.415 & 0.035 \\
\hline
\end{tabular}


Table 5

Stochastic efficient weighting for each sub-index for overall risk

\begin{tabular}{|c|c|c|c|c|}
\hline \multicolumn{5}{|c|}{ Stochastic efficient weighting for each sub-index } \\
\hline $\begin{array}{c}\text { Number of } \\
\text { observations }\end{array}$ & $\begin{array}{c}\text { Number of } \\
\text { dominating } \\
\text { weighting schemes }\end{array}$ & Economic Risk & Political Risk & $\begin{array}{c}\text { Financial and } \\
\text { Banking Sector } \\
\text { Risk }\end{array}$ \\
\hline $\mathrm{N}$ & $\mathrm{n}$ & \multicolumn{3}{|c|}{ Average of dominating weighting schemes } \\
\hline 214 & 190 & 0.148 & 0.078 & 0.774 \\
\hline
\end{tabular}


Table 6

Rankings of emerging market countries for economic, political, financial and banking risk and overall risk

\begin{tabular}{|c|c|c|c|c|c|}
\hline \multicolumn{2}{|l|}{ Economic risk rankings in 2008, 2009, and 2010 } \\
\hline Country & $\mathbf{2 0 0 8}$ & Country & $\mathbf{2 0 0 9}$ & Country & $\mathbf{2 0 1 0}$ \\
\hline Pakistan & 0.6798 & Mexico & 0.7800 & Hungary & 0.6829 \\
\hline Hungary & 0.6560 & Turkey & 0.7728 & Ecuador & 0.6633 \\
\hline Turkey & 0.6341 & Hungary & 0.7717 & Turkey & 0.6442 \\
\hline Thailand & 0.6104 & Thailand & 0.7568 & Pakistan & 0.6431 \\
\hline Mexico & 0.6006 & Russia & 0.7531 & Thailand & 0.6398 \\
\hline Philippines & 0.5752 & Malaysia & 0.7449 & Poland & 0.6193 \\
\hline Malaysia & 0.5672 & Ecuador & 0.7448 & Argentina & 0.6124 \\
\hline Vietnam & 0.5559 & Romania & 0.7082 & Bulgaria & 0.6120 \\
\hline Poland & 0.5525 & Bulgaria & 0.7014 & Malaysia & 0.6101 \\
\hline Colombia & 0.5493 & Philippines & 0.6839 & Romania & 0.6078 \\
\hline India & 0.5492 & Argentina & 0.6833 & Vietnam & 0.5983 \\
\hline Ecuador & 0.5488 & Poland & 0.6580 & Philippines & 0.5968 \\
\hline Indonesia & 0.5363 & Colombia & 0.6370 & Mexico & 0.5929 \\
\hline Romania & 0.5245 & Brazil & 0.6360 & Indonesia & 0.5842 \\
\hline Brazil & 0.5240 & Iran & 0.6312 & Peru & 0.5815 \\
\hline Iran & 0.5147 & Pakistan & 0.6219 & Colombia & 0.5808 \\
\hline Bulgaria & 0.5116 & Vietnam & 0.6132 & Russia & 0.5754 \\
\hline Argentina & 0.4881 & Peru & 0.6098 & Brazil & 0.5749 \\
\hline China & 0.4762 & Venezuela & 0.6065 & Venezuela & 0.5627 \\
\hline Russia & 0.4383 & Indonesia & 0.6009 & Iran & 0.5569 \\
\hline Peru & 0.4368 & India & 0.5691 & India & 0.5496 \\
\hline Chile & 0.3723 & Chile & 0.5134 & China & 0.5060 \\
\hline Venezuela & 0.3335 & China & 0.5082 & Chile & 0.4380 \\
\hline Nigeria & 0.2754 & Nigeria & 0.4529 & Nigeria & 0.4096 \\
\hline
\end{tabular}


Table 6 (continued)

\begin{tabular}{|c|c|c|c|c|c|}
\hline \multicolumn{6}{|c|}{ Political risk rankings in 2008, 2009, and 2010} \\
\hline Country & 2008 & Country & 2009 & Country & 2010 \\
\hline Nigeria & 0.7702 & Nigeria & 0.7702 & Venezuela & 0.7688 \\
\hline Venezuela & 0.7456 & Venezuela & 0.7606 & Nigeria & 0.7687 \\
\hline Kazakhstan & 0.7316 & Kazakhstan & 0.7337 & Ecuador & 0.7342 \\
\hline Azerbaijan & 0.7184 & Ecuador & 0.7270 & Kazakhstan & 0.7342 \\
\hline Ecuador & 0.7117 & Azerbaijan & 0.7200 & Azerbaijan & 0.7200 \\
\hline Ukraine & 0.6958 & Ukraine & 0.6953 & Ukraine & 0.6947 \\
\hline Russia & 0.6845 & Russia & 0.6822 & Russia & 0.6795 \\
\hline China & 0.6811 & Indonesia & 0.6652 & Indonesia & 0.6652 \\
\hline Indonesia & 0.6637 & China & 0.6650 & China & 0.6422 \\
\hline Iran & 0.6442 & Iran & 0.6423 & Iran & 0.6401 \\
\hline Peru & 0.6391 & Vietnam & 0.6314 & Vietnam & 0.6272 \\
\hline Vietnam & 0.6372 & Pakistan & 0.6221 & Saudi Arabia & 0.6219 \\
\hline Pakistan & 0.6337 & Saudi Arabia & 0.6220 & Philippines & 0.6049 \\
\hline Saudi Arabia & 0.6221 & Peru & 0.6203 & Pakistan & 0.6029 \\
\hline Algeria & 0.6199 & Philippines & 0.6049 & Peru & 0.5953 \\
\hline Philippines & 0.6049 & Algeria & 0.6034 & Algeria & 0.5803 \\
\hline Bulgaria & 0.5701 & Bulgaria & 0.5681 & Bulgaria & 0.5676 \\
\hline Turkey & 0.5575 & Turkey & 0.5576 & Turkey & 0.5577 \\
\hline Thailand & 0.5533 & Thailand & 0.5549 & Thailand & 0.5549 \\
\hline Romania & 0.5318 & Romania & 0.5165 & Brazil & 0.5146 \\
\hline Colombia & 0.5166 & Brazil & 0.5146 & Colombia & 0.5119 \\
\hline Brazil & 0.5146 & Colombia & 0.5142 & Mexico & 0.5085 \\
\hline India & 0.5145 & Mexico & 0.5086 & Romania & 0.5012 \\
\hline Egypt & 0.5110 & Argentina & 0.4984 & Argentina & 0.5000 \\
\hline Mexico & 0.5087 & India & 0.4972 & Sri Lanka & 0.4955 \\
\hline Argentina & 0.4967 & Sri Lanka & 0.4961 & Egypt & 0.4766 \\
\hline Sri Lanka & 0.4966 & Egypt & 0.4938 & India & 0.4724 \\
\hline South Africa & 0.4537 & South Africa & 0.4210 & Poland & 0.4000 \\
\hline Poland & 0.4013 & Poland & 0.3999 & Hungary & 0.3974 \\
\hline Hungary & 0.3982 & Hungary & 0.3978 & South Africa & 0.3880 \\
\hline Malaysia & 0.3707 & Malaysia & 0.3733 & Malaysia & 0.3775 \\
\hline Chile & 0.2988 & Chile & 0.2992 & Chile & 0.3011 \\
\hline
\end{tabular}


Table 6 (continued)

\begin{tabular}{|c|c|}
\hline Financial and banking risk rankings in 2008 \\
\hline Country & $\mathbf{2 0 0 8}$ \\
\hline Hungary & 0.7128 \\
\hline China & 0.6959 \\
\hline Ukraine & 0.6879 \\
\hline Pakistan & 0.6810 \\
\hline Thailand & 0.6786 \\
\hline Indonesia & 0.6681 \\
\hline Kazakhstan & 0.6638 \\
\hline Argentina & 0.6577 \\
\hline Venezuela & 0.6552 \\
\hline Bulgaria & 0.6531 \\
\hline Philippines & 0.6212 \\
\hline Turkey & 0.6100 \\
\hline India & 0.5893 \\
\hline Brazil & 0.5789 \\
\hline Colombia & 0.5663 \\
\hline Peru & 0.5604 \\
\hline Malaysia & 0.5504 \\
\hline Nigeria & 0.5469 \\
\hline Poland & 0.5312 \\
\hline Mexico & 0.4757 \\
\hline Chile & 0.4704 \\
\hline & \\
\hline & \\
\hline
\end{tabular}

\begin{tabular}{|c|c|}
\hline \multicolumn{2}{|c|}{ Overall risk rankings in 2008 } \\
\hline Country & $\mathbf{2 0 0 8}$ \\
\hline Hungary & 0.6798 \\
\hline Pakistan & 0.6771 \\
\hline China & 0.6623 \\
\hline Thailand & 0.6588 \\
\hline Indonesia & 0.6483 \\
\hline Bulgaria & 0.6257 \\
\hline Argentina & 0.6200 \\
\hline Venezuela & 0.6146 \\
\hline Philippines & 0.6131 \\
\hline Turkey & 0.6095 \\
\hline India & 0.5775 \\
\hline Brazil & 0.5658 \\
\hline Colombia & 0.5599 \\
\hline Peru & 0.5482 \\
\hline Malaysia & 0.5389 \\
\hline Poland & 0.5242 \\
\hline Nigeria & 0.5241 \\
\hline Mexico & 0.4967 \\
\hline Chile & 0.4425 \\
\hline
\end{tabular}


Table 7

Country rating rankings of the S\&P and FITCH

\begin{tabular}{|c|c|c|c|c|c|c|}
\hline \multicolumn{3}{|c|}{ S\&P Rankings in 2008} & \multirow[b]{2}{*}{ Rank } & \multicolumn{3}{|c|}{ FITCH Rankings in 2008} \\
\hline Country & S\&P Rating & S\&P Mapping & & Country & FITCH Rating & FITCH Mapping \\
\hline Ecuador & SD & 1 & 1 & Argentina & $\mathrm{RD}$ & 0.99 \\
\hline Pakistan & $\mathrm{CCC}+$ (developing) & 0.8 & 2 & Ecuador & $\mathrm{RD}$ & 0.99 \\
\hline Argentina & B- $($ stable $)$ & 0.75 & 3 & Ukraine & $\mathrm{B}+$ (negative) & 0.66 \\
\hline Ukraine & B (negative) & 0.71 & 4 & Sri Lanka & $\mathrm{B}+($ stable $)$ & 0.65 \\
\hline Sri Lanka & B (stable) & 0.7 & 5 & Venezuela & $\mathrm{B}+($ stable $)$ & 0.65 \\
\hline Turkey & BB- (negative) & 0.61 & 6 & Vietnam & BB- (negative) & 0.61 \\
\hline Venezuela & BB- (negative) & 0.61 & 7 & Nigeria & BB- (stable) & 0.6 \\
\hline Indonesia & BB- (stable) & 0.6 & 8 & Turkey & BB- (stable) & 0.6 \\
\hline Nigeria & BB- (stable) & 0.6 & 9 & Indonesia & BB (stable) & 0.55 \\
\hline Philippines & BB- (stable) & 0.6 & 10 & Philippines & BB (stable) & 0.55 \\
\hline Vietnam & BB (negative) & 0.56 & 11 & Romania & $\mathrm{BB}+$ (negative) & 0.51 \\
\hline Romania & BB+ (negative) & 0.51 & 12 & Colombia & $\mathrm{BB}+($ stable $)$ & 0.5 \\
\hline Colombia & BB+ (stable $)$ & 0.5 & 13 & Egypt & BB+ (stable $)$ & 0.5 \\
\hline Egypt & $\mathrm{BB}+($ stable $)$ & 0.5 & 14 & Azerbaijan & $\mathrm{BB}+($ stable $)$ & 0.5 \\
\hline Azerbaijan & $\mathrm{BB}+($ stable $)$ & 0.5 & 15 & Kazakhstan & BBB- (negative) & 0.46 \\
\hline Kazakhstan & BBB- (negative) & 0.46 & 16 & Brazil & BBB- (stable) & 0.45 \\
\hline Brazil & BBB- (stable) & 0.45 & 17 & Bulgaria & BBB- (stable) & 0.45 \\
\hline India & BBB- (stable) & 0.45 & 18 & India & BBB- (stable) & 0.45 \\
\hline Peru & BBB- (stable) & 0.45 & 19 & Peru & BBB- (stable) & 0.45 \\
\hline Bulgaria & BBB (negative) & 0.41 & 20 & Hungary & BBB (stable) & 0.4 \\
\hline Hungary & BBB (negative) & 0.41 & 21 & Mexico & $\mathrm{BBB}+$ (negative) & 0.36 \\
\hline Russia & BBB (negative) & 0.41 & 22 & Russia & $\mathrm{BBB}+$ (negative) & 0.36 \\
\hline South Africa & $\mathrm{BBB}+$ (negative) & 0.36 & 23 & South Africa & $\mathrm{BBB}+$ (negative) & 0.36 \\
\hline Thailand & $\mathrm{BBB}+$ (negative) & 0.36 & 24 & Thailand & $\mathrm{BBB}+$ (negative) & 0.36 \\
\hline Mexico & $\mathrm{BBB}+($ stable $)$ & 0.35 & 25 & Malaysia & A- (stable $)$ & 0.3 \\
\hline Malaysia & A- (stable) & 0.3 & 26 & Poland & A- (stable) & 0.3 \\
\hline Poland & A- (stable) & 0.3 & 27 & Chile & A (stable) & 0.25 \\
\hline Chile & $\mathrm{A}+($ stable $)$ & 0.2 & 28 & China & $\mathrm{A}+($ stable $)$ & 0.2 \\
\hline China & $\mathrm{A}+($ stable $)$ & 0.2 & 29 & Saudi Arabia & AA- (stable) & 0.15 \\
\hline Saudi Arabia & AA- (stable) & 0.15 & 30 & & & \\
\hline
\end{tabular}

Note: Rankings for the S\&P and FITCH are ordered from riskiest to least risky emerging country for the period 2008. S\&P have ratings for 30 emerging countries where

Algeria and Iran have no ratings for 2008 period. Whereas, FITCH have rating for 29 countries where Algeria, Iran and Pakistan have no ratings for 2008 period. 
Table 7 (continued)

\begin{tabular}{|c|c|c|c|c|c|c|}
\hline \multicolumn{7}{|c|}{ Country rating rankings of the S\&P in 2009 and 2010} \\
\hline \multicolumn{3}{|c|}{ S\&P Rankings in 2009} & \multirow[b]{2}{*}{ Rank } & \multicolumn{3}{|c|}{ S\&P Rankings in 2010} \\
\hline Country & S\&P Rating & S\&P Mapping & & Country & S\&P Rating & S\&P Mapping \\
\hline Ecuador & $\mathrm{CCC}+($ stable $)$ & 0.8 & 1 & Ecuador & $\mathrm{CCC}+($ stable $)$ & 0.8 \\
\hline Ukraine & $\mathrm{CCC}+($ stable $)$ & 0.8 & 2 & Argentina & B- (stable) & 0.75 \\
\hline Argentina & B- (stable) & 0.75 & 3 & Pakistan & B- (stable) & 0.75 \\
\hline Pakistan & B- (stable) & 0.75 & 4 & Ukraine & B- (positive) & 0.74 \\
\hline Sri Lanka & B (positive) & 0.69 & 5 & Sri Lanka & B (positive) & 0.69 \\
\hline Nigeria & $\mathrm{B}+($ stable $)$ & 0.65 & 6 & Nigeria & $\mathrm{B}+($ stable $)$ & 0.65 \\
\hline Venezuela & BB- (negative) & 0.61 & 7 & Philippines & BB- (stable) & 0.6 \\
\hline Philippines & BB- (stable) & 0.6 & 8 & Venezuela & BB- (stable) & 0.6 \\
\hline Turkey & BB- (stable) & 0.6 & 9 & Vietnam & BB (negative) & 0.56 \\
\hline Indonesia & BB- (positive) & 0.59 & 10 & Indonesia & BB (positive) & 0.54 \\
\hline Vietnam & BB (negative) & 0.56 & 11 & Turkey & BB (positive) & 0.54 \\
\hline Romania & BB+ (negative) & 0.51 & 12 & Colombia & $\mathrm{BB}+($ stable $)$ & 0.5 \\
\hline Colombia & $\mathrm{BB}+($ stable $)$ & 0.5 & 13 & Egypt & $\mathrm{BB}+($ stable $)$ & 0.5 \\
\hline Egypt & $\mathrm{BB}+($ stable $)$ & 0.5 & 14 & Romania & $\mathrm{BB}+($ stable $)$ & 0.5 \\
\hline Azerbaijan & $\mathrm{BB}+$ (positive) & 0.49 & 15 & Azerbaijan & $\mathrm{BB}+$ (positive) & 0.49 \\
\hline India & BBB- (negative) & 0.46 & 16 & India & BBB- (negative) & 0.46 \\
\hline Brazil & BBB- (stable) & 0.45 & 17 & Brazil & BBB- (stable) & 0.45 \\
\hline Hungary & BBB- (stable) & 0.45 & 18 & Hungary & BBB- (stable) & 0.45 \\
\hline Kazakhstan & BBB- (stable) & 0.45 & 19 & Kazakhstan & BBB- (stable) & 0.45 \\
\hline Peru & BBB- (stable) & 0.45 & 20 & Peru & BBB- (stable) & 0.45 \\
\hline Bulgaria & BBB (stable) & 0.4 & 21 & Bulgaria & BBB (stable) & 0.4 \\
\hline Mexico & BBB (stable) & 0.4 & 22 & Mexico & BBB (stable) & 0.4 \\
\hline Russia & BBB (stable) & 0.4 & 23 & Russia & BBB (stable) & 0.4 \\
\hline South Africa & $\mathrm{BBB}+$ (negative) & 0.36 & 24 & South Africa & $\mathrm{BBB}+$ (negative) & 0.36 \\
\hline Thailand & $\mathrm{BBB}+$ (negative) & 0.36 & 25 & Thailand & $\mathrm{BBB}+$ (negative) & 0.36 \\
\hline Malaysia & A- (stable $)$ & 0.3 & 26 & Malaysia & A- (stable $)$ & 0.3 \\
\hline Poland & A- (stable) & 0.3 & 27 & Poland & A- (stable) & 0.3 \\
\hline Chile & $\mathrm{A}+($ stable $)$ & 0.2 & 28 & Chile & $\mathrm{A}+($ stable $)$ & 0.2 \\
\hline China & $\mathrm{A}+($ stable $)$ & 0.2 & 29 & China & A+ (stable $)$ & 0.2 \\
\hline Saudi Arabia & AA- (stable) & 0.15 & 30 & Saudi Arabia & AA- (stable) & 0.15 \\
\hline
\end{tabular}


Table 8

Spearman rank correlation between S\&P and FITCH rating rankings and the optimal economic, political, financial and overall risk rankings

\begin{tabular}{|l|c|c|c|c|c|}
\hline Spearman Rank correlation between S\&P ranking and optimal rankings in 2008 \\
\hline & Mapping S\&P & Economic & Political & Financial & Overall \\
\hline Mapping S\&P & 1 & & & & \\
\hline Economic & 0.0503 & 1 & & & \\
\hline Political & $0.4674 * *$ & -0.3386 & 1 & & \\
\hline Financial & 0.3236 & 0.2754 & 0.3386 & 1 & 1 \\
\hline Overall & 0.3016 & 0.3298 & 0.3088 & $0.9912 *$ & 1 \\
\hline $\begin{array}{l}\text { Note: } 19 \text { countries that have overlapping data for all indices are used to obtain the spearman rank correlations. *, ** and *** } \\
\text { denotes the significance of the spearman rank correlation at } 1 \%, 5 \% \text { and } 10 \% \text { level respectively. Spearman rank correlation is } \\
\text { significant between the S\&P ranking and our political risk ranking. }\end{array}$ \\
\hline
\end{tabular}

\begin{tabular}{|c|c|c|c|c|c|}
\hline \multicolumn{6}{|c|}{ Spearman Rank correlation between S\&P ranking and optimal rankings in 2008 (Separate analysis) } \\
\hline & & Economic & Political & Financial & Overall \\
\hline $\begin{array}{l}\text { Number of } \\
\text { observations }\end{array}$ & & 23 & 30 & 21 & 19 \\
\hline Spearman's Rho & S\&P & 0.0436 & $0.3943 * *$ & 0.3462 & 0.3016 \\
\hline \multicolumn{6}{|c|}{$\begin{array}{l}\text { Note: The Spearman rank correlation between the S\&P ranking and each optimal index's ranking is analyzed separately. The first } \\
\text { row offers the number of countries used to obtain the Spearman's rho coefficient between S\&P and each respective index. The } \\
\text { second row offers the Spearman's rho coefficients. *, ** and *** denotes the significance of the spearman rank correlation at } 1 \% \text {, } \\
5 \% \text { and } 10 \% \text { level respectively. }\end{array}$} \\
\hline
\end{tabular}

\begin{tabular}{|l|c|c|c|c|c|}
\hline Spearman Rank correlation between FITCH ranking and optimal rankings in 2008 \\
\hline & $\begin{array}{l}\text { Mapping } \\
\text { FITCH }\end{array}$ & Economic & Political & Financial & Overall \\
\hline $\begin{array}{l}\text { Mapping } \\
\text { FITCH }\end{array}$ & 1 & & & & \\
\hline Economic & -0.1882 & 1 & & & \\
\hline Political & $0.4730^{* *}$ & $-0.4421^{* * *}$ & 1 & & \\
\hline Financial & 0.2183 & 0.1785 & 0.3209 & 1 & 1 \\
\hline Overall & 0.1601 & 0.2136 & 0.2962 & $0.9917 *$ & \\
\hline $\begin{array}{l}\text { Note: } 18 \text { countries that have overlapping data for all indices are used to obtain the spearman rank correlations *, **and } * * * \\
\text { denotes the significance of the spearman rank correlation at } 1 \%, 5 \% \text { and } 10 \% \text { level respectively. Spearman rank correlation is } \\
\text { significant between FITCH ranking and our political risk ranking. }\end{array}$ \\
\hline
\end{tabular}

\begin{tabular}{|l|c|c|c|c|c|}
\hline \multicolumn{5}{|l|}{ Spearman Rank correlation between FITCH ranking and optimal rankings in 2008 (Separate analysis) } \\
\hline & & Economic & Political & Financial & Overall \\
\hline $\begin{array}{l}\text { Number of } \\
\text { observations }\end{array}$ & 22 & 29 & 20 & 18 \\
\hline Spearman's Rho & FITCH & -0.0902 & $0.3815^{* *}$ & 0.2578 & 0.1601 \\
\hline $\begin{array}{l}\text { Note: The Spearman rank correlation between FITCH ranking and each optimal index's ranking is analyzed separately. The first } \\
\text { row offers the number of countries used to obtain the Spearman's rho coefficient between FITCH and each respective index } \\
\text { ranking. The second row offers the Spearman's rho coefficients. *, ** and *** denotes the significance of the spearman rank } \\
\text { correlation at 1\%, 5\% and 10\% level respectively. }\end{array}$ \\
\hline
\end{tabular}


Table 9

Relative ranking differences between the optimal overall risk and the S\&P ratings in 2008

\begin{tabular}{|c|c|c|}
\hline Optimal Overall Risk & \multicolumn{2}{|c|}{ S\&P Ratings } \\
\hline 0.6798 & Hungary & $\mathrm{CCC}+$ (developing) \\
\hline 0.6771 & / Argentina & B- (stable $)$ \\
\hline 0.6623 & Turkey & BB- (negative) \\
\hline 0.6588 & Thailand & BB- (negative) \\
\hline 0.6483 & Indonesia & BB- (stable) \\
\hline 0.6257 & Bulgaria & BB- (stable) \\
\hline 0.6200 & Argentina & BB- (stable) \\
\hline 0.6146 & Venezuela & $\mathrm{BB}+($ stable $)$ \\
\hline 0.6131 & Philippines & BBB- (stable) \\
\hline 0.6095 & Turkey $\quad /$ & BBB- (stable) \\
\hline 0.5775 & India & BBB- (stable) \\
\hline 0.5658 & Bulgaria & BBB (negative) \\
\hline 0.5599 & Colombia & BBB (negative) \\
\hline 0.5482 & Thailand & $\mathrm{BBB}+$ (negative) \\
\hline 0.5389 & Mexico & $\mathrm{BBB}+($ stable $)$ \\
\hline 0.5242 & - Malaysia & A- (stable) \\
\hline 0.5241 & Nigeria & A- (stable) \\
\hline 0.4967 & Mexico & $\mathrm{A}+($ stable $)$ \\
\hline 0.4425 & Chile $\longrightarrow$ China & $\mathrm{A}+($ stable $)$ \\
\hline \multicolumn{3}{|c|}{$\begin{array}{l}\text { Vote: Rankings for the optimal overall risk and S\&P are ordered from riskiest to least risky } \\
\text { emerging country for the period 2008. } 19 \text { countries that have overlapping data for both indices are } \\
\text { ised for comparison. The lines between the two lists indicate changes in relative ranking. }\end{array}$} \\
\hline
\end{tabular}


Table 10

Spearman rank correlation between sovereign bond interest rate spreads and the optimal economic, political, financial and overall risk rankings

\begin{tabular}{|l|c|c|c|c|c|}
\hline Spearman rank correlation between sovereign bond spreads and optimal risk rankings \\
\hline & $\begin{array}{l}\text { Bond interest } \\
\text { rate spreads }\end{array}$ & $\begin{array}{l}\text { Economic } \\
\text { risk index }\end{array}$ & $\begin{array}{l}\text { Political } \\
\text { risk index }\end{array}$ & $\begin{array}{l}\text { Financial } \\
\text { risk index }\end{array}$ & $\begin{array}{l}\text { Overall } \\
\text { risk index }\end{array}$ \\
\hline Bond interest rate spreads & 1 & & & & \\
\hline Economic risk index & 0.2230 & 1 & & & \\
\hline Political risk index & 0.2402 & -0.3775 & 1 & & \\
\hline Financial risk index & $0.4926^{* *}$ & 0.2108 & 0.3456 & 1 & \\
\hline Overall risk index & $0.4975^{* *}$ & 0.2794 & 0.3039 & 0.9877 & 1 \\
\hline $\begin{array}{l}\text { Note: } 17 \text { countries that have overlapping data for all indices are used to obtain the spearman rank correlations. *,** } \\
\text { and } * * * \text { denotes the significance of the spearman rank correlation at 1\%, 5\% and 10\% level respectively. Spearman } \\
\text { rank correlation is significant between sovereign bond spreads \& our financial and overall rankings. }\end{array}$ \\
\hline
\end{tabular}

\begin{tabular}{|c|c|c|c|c|c|}
\hline \multicolumn{6}{|c|}{$\begin{array}{l}\text { Spearman rank correlation between sovereign bond spreads and optimal risk rankings } \\
\text { (Separate analysis }\end{array}$} \\
\hline & & $\begin{array}{l}\text { Economic } \\
\text { risk index }\end{array}$ & $\begin{array}{c}\text { Political } \\
\text { risk index }\end{array}$ & $\begin{array}{l}\text { Financial } \\
\text { risk index }\end{array}$ & $\begin{array}{l}\text { Overall } \\
\text { risk index }\end{array}$ \\
\hline $\begin{array}{l}\text { Number of } \\
\text { observations }\end{array}$ & & 20 & 25 & 19 & 17 \\
\hline Spearman's Rho & $\begin{array}{l}\text { Bond interest } \\
\text { rate spreads }\end{array}$ & 0.1624 & $0.3423 * * *$ & $0.5105^{* *}$ & $0.4975 * *$ \\
\hline \multicolumn{6}{|c|}{$\begin{array}{l}\text { Note: The Spearman rank correlation between the bond interest rate spreads and each optimal index's ranking is } \\
\text { analyzed separately. The first row offers the number of countries used to obtain the Spearman's rho coefficient } \\
\text { between the bond interest rate spreads and each respective index. The second row offers the Spearman's rho } \\
\text { coefficient. *,** and } * * * \text { denotes the significance of the spearman rank correlation at } 1 \%, 5 \% \text { and } 10 \% \text { level } \\
\text { respectively. }\end{array}$} \\
\hline
\end{tabular}

